\author{
Universidade de São Paulo \\ Faculdade de Medicina de Ribeirão Preto \\ Pós-Graduação em Imunologia Básica e Aplicada
}

Valter Vinícius Silva Monteiro

O papel do STING na imunopatologia da sepse

Ribeirão Preto

2020 


\author{
Universidade de São Paulo \\ Faculdade de Medicina de Ribeirão Preto \\ Pós-Graduação em Imunologia Básica e Aplicada
}

Valter Vinícius Silva Monteiro

\title{
O papel do STING na imunopatologia da sepse
}

\begin{abstract}
Dissertação apresentada ao Programa de Pósgraduação em Imunologia Básica e Aplicada da Faculdade de Medicina de Ribeirão Preto da Universidade de São Paulo para obtenção do título de mestre em ciências, na área de concentração: Imunologia Básica e Aplicada.
\end{abstract}

Orientador: Prof. Dr. Fernando de Queiroz Cunha

Ribeirão Preto 
Autorizo a reprodução e divulgação total ou parcial deste trabalho por qualquer meio convencional ou eletrônico para fins de estudo e pesquisa desde que citada a fonte.

Monteiro, Valter Vinícius Silva.

O papel do STING na imunopatologia da sepse

$64 \mathrm{p} ; 30 \mathrm{~cm}$

Dissertação apresentada ao programa de pós-graduação em Imunologia Básica e Aplicada da Faculdade de Medicina de Ribeirão Preto da Universidade de São Paulo para obtenção do título de Mestre em Ciências, na área de concentração: Imunologia Básica e Aplicada.

Orientador: Prof. Dr. Fernando de Queiroz Cunha.

1. Sepse. 2. STING. 3. DNA extracelular. 
Valter Vinícius Silva Monteiro

\section{O papel do STING na imunopatologia da sepse}

Dissertação apresentada ao programa de pósgraduação em Imunologia Básica e Aplicada da Faculdade de Medicina de Ribeirão Preto da Universidade de São Paulo para obtenção do título de mestre em ciências, na área de concentração: imunologia básica e aplicada.

Orientador: Prof. Dr. Fernando de Queiroz Cunha

Aprovado em: de de

\section{BANCA EXAMINADORA}

Prof. Dr. Fernando de Queiroz Cunha

Faculdade de Medicina de Ribeirão Preto - USP

Prof. Dr. Alexandre Alarcon Steiner

Instituto de Ciências Biológicas - USP

Prof. Dr. Sergio Costa Oliveira

Instituto de Ciências Biológicas - UFMG 
Dedico este trabalho a toda a minha família, em especial a meus pais 


\section{AGRADECIMENTOS}

À toda minha família, em especial a meus pais, pois devo muito a eles a pessoa que sou hoje, por estarem sempre presentes durante todos os momentos e apoiarem minhas escolhas e nos meus sonhos.

Ao meu orientador, Professor Dr. Fernando de Queiroz Cunha, por tudo que me ensinou durante o tempo em que passei no laboratório, esses ensinamentos contribuíram muito para minha vida acadêmica e pessoal.

Aos demais Professores do Laboratório de Inflamação e Dor, Prof. Dr. Thiago Mattar Cunha, e Prof. Dr. José Carlos Alves Filho, pelas contribuições científicas e ensinamentos que contribuíram para o meu crescimento científico.

Agradeço aos Professores, Dr. Alexandre Alarcon Steiner e Dra. Sergio Costa Oliveira, pela disponibilidade de participar desta banca examinadora, que será de grande valor para as discussões e aperfeiçoamento deste trabalho.

Aos meus colaboradores desse trabalho, em especial ao Bráulio, a Camila e ao Guilherme, pela amizade, por terem me ensinado a realizar as técnicas aplicadas no trabalho e pela contribuição intelectual na realização e delineamento do projeto.

A Rose, pelo companheirismo de todas as horas e por sempre estar presente nos momentos de dificuldade.

Aos amigos que fiz em Ribeirão Preto, todos contribuíram de alguma forma para que a conclusão desse projeto fosse possível, seja nos momentos de descontração quanto nos momentos de trabalho.

Às agências de fomento, Coordenação de Aperfeiçoamento Pessoal de Nível Superior (CAPES), Conselho Nacional de Desenvolvimento Tecnológico e Científico (CNPQ), Fundação de Amparo à Pesquisa do Estado de São Paulo (FAPESP) e ao 
Centerfor Research in Inflammatory Diseases (CRID) pelo apoio financeiro fundamental para desenvolvimento deste trabalho.

Muito obrigado a todos! 
"Uma mente necessita de livros da mesma forma que uma espada necessita de uma pedra de amolar, se quisermos que se mantenha afiada."

George R. R. Martin 


\section{LISTA DE FIGURAS}

Figura 1. Cinética do DNA plasmático nos modelos de sepse moderada e

letal. .36

Figura 2. Neutrófilos estimulados com DNA produzem NETs. .38

Figura 3. Animais deficientes para os receptores de DNA STING e TLR9, mas não AIM2, possuem uma maior sobrevida na sepse letal.

Figura 4. Animais deficientes para STING possuem uma menor carga bacteriana.

Figura 5. Camundongos defientes para STING possuem menos DNA plasmático na sepse. .44

Figura 6. Deficiência de STING diminui a lesão de órgão na sepse. .48

Figura 7. Deficiência de STING diminui a produção de citocinas na sepse. 50 


\section{Resumo}

A sepse é uma síndrome complexa causada pela resposta imune desregulada desencadeada por uma infecção, levando a disfunção de órgãos. Uma característica comum descrita na sepse é a presença de altos níveis de DNA circulante (cfDNA) no plasma desses pacientes. Nesse sentido, foi demonstrado que existe uma correlação positiva entre os níveis de DNA e a mortalidade de pacientes com sepse. Portando, fazse necessário uma melhor investigação acerca dos mecanismos através dos quais o DNA extracelular contribui para fisiopatologia da sepse. Com base nisso, o objetivo deste estudo é investigar as características dos cfDNA e seu papel na patogênese da sepse. Nesse sentido, utilizamos o modelo de CLP em camundongos deficientes deTLR9, STING e AIM2 para avaliar o papel de cada receptor no prognóstico da sepse. Observamos que o receptor de DNA, STING, está envolvido na produção de NETs durante a sepse. A estimulação de neutrófilos com DNA é capaz de induzir a produção de NETs in vitro e quando utilizados camundongos deficientes para o receptor STING, animais submetidos ao modelo de sepse letal possuem uma maior sobrevida e uma menor carga bacteriana. Além disso, esse animais possuem uma menor produção de NETs, citocinas e lesão de órgãos. Deste modo, podemos concluir que o STING está envovido na patogenese da sepse induzindo a produção de NETs.

Palavras-chave: sepse, ácidos nucleicos extracelulares, DNA extracelular, PRR, STING, TLR9, AIM2 


\begin{abstract}
Sepsis is a syndrome caused by the unregulated immune response triggered by an infection, leading to organ dysfunction. A common feature described in sepsis is the presence of high levels of circulating cell-free DNA (cfDNA) in the plasma of these patients. In this sense, it has been shown that there is a positive correlation between DNA levels in the plasma and mortality in patients with sepsis. Therefore, a better investigation about the mechanisms through which extracellular DNA contributes to the pathophysiology of sepsis is necessary. Based on this, the aim of this study is to investigate the characteristics of cfDNA and its role in the pathogenesis of sepsis. In this sense, we used the PLC model in TLR9, STING and AIM2 deficient mice to assess the role of each receptor in the prognosis of sepsis. We observed that the DNA receptor, STING, is involved in the production of NETs during sepsis. Stimulation of neutrophils with DNA is able to induce the production of NETs in vitro and when mice deficient for the STING receptor, animals submitted to the lethal sepsis model have a longer survival and a lower bacterial load. In addition, these animals have a lower production of NETs, cytokines and organ damage. Thus, we can conclude that STING is involved in the pathogenesis of sepsis, inducing the production of NETs.
\end{abstract}

Key-words: Sepsis, Cell-free Nucleic acids, Cell-free DNA, PRR, STING, TLR9, AIM2 


\section{SUMÁRIO}

1. INTRODUÇÃO

1.1. DEFINIÇÃO E EPIDEMIOLOGIA DA SEPSE ................................14

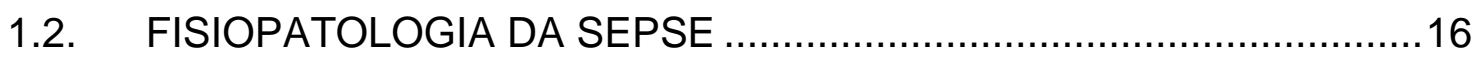

1.3. RECEPTORES DE DNA NA SEPSE ........................................19

1.4. PAPEL DOS NEUTRÓFILOS NA SEPSE.......................................22

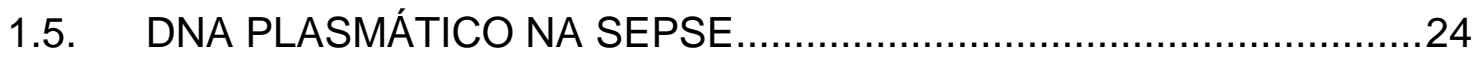

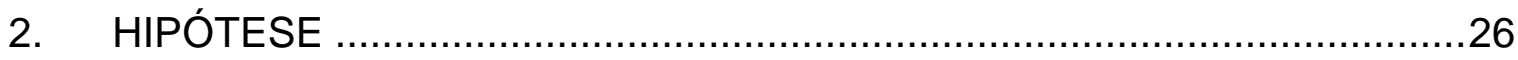

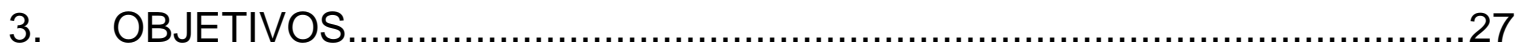

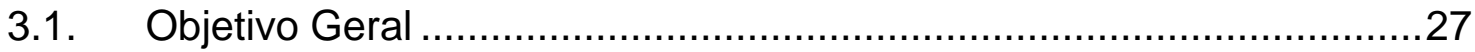

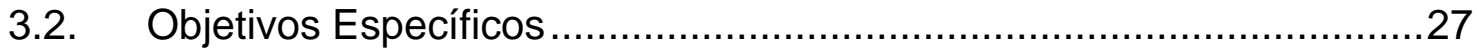

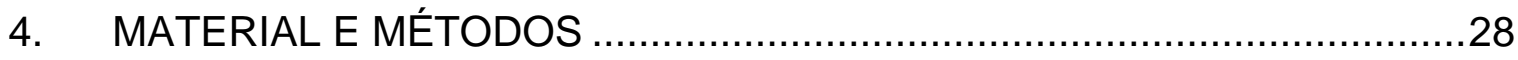

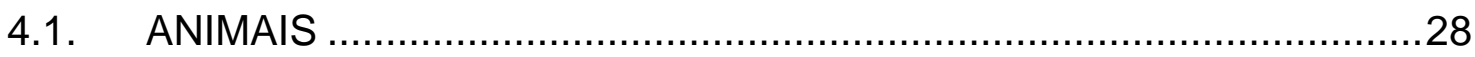

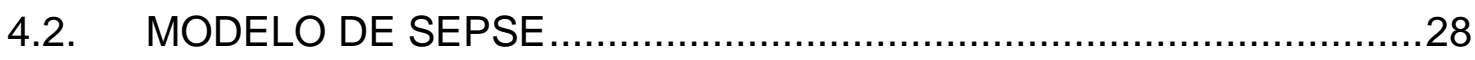

4.3. COLETA DE CÉLULAS DO SANGUE E PLASMA ….........................29

4.4. COLETA DO LAVADO PERITONEAL .........................................29

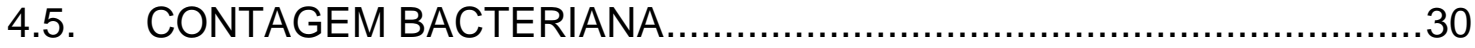

4.6. DETERMINAÇÃO DOS NÍVEIS DE CITOCINAS ................................30

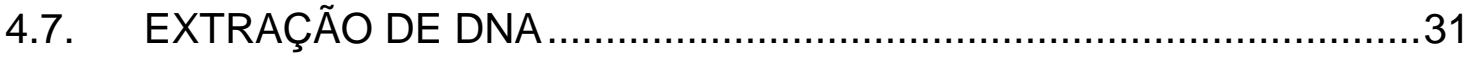

4.8. PURIFICAÇÃO DE NEUTRÓFILOS ……........................................

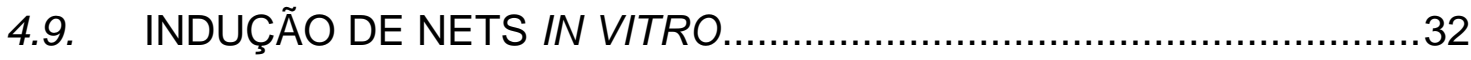

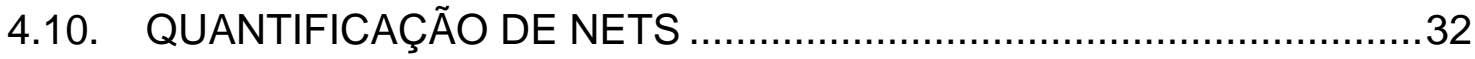

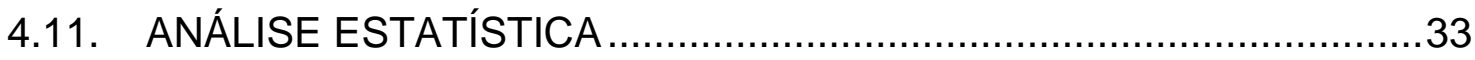

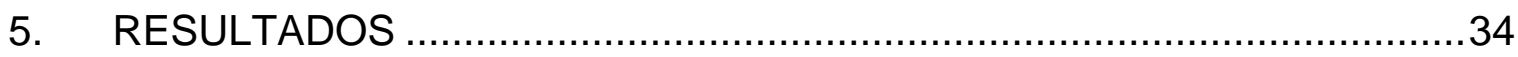

5.1. Aumentadas concentrações de DNA livre plasmático são encontradas em estímulos sépticos de diferentes intensidades. 
5.2. Neutrófilos estimulados com diferentes tipos de DNA induzem a

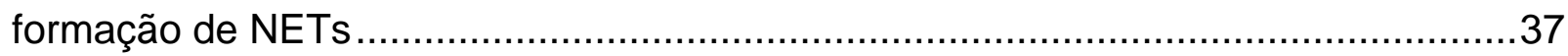

5.3. Camundongos deficientes em STING e TLR-9, mas não AIM2, possuem maior sobrevida após sepse letal.

5.4. A deficiência de STING está associada a uma menor disseminação bacteriana após sepse letal

5.5. A deficiência em STING está associada com menores concentrações de DNA e NETs no plasma de camundongos após sepse letal.

5.6. A deficiência em STING está associada ao menor desenvolvimento de lesões orgânicas após sepse letal .45

5.7. A deficiência em STING resulta em menor produção de citocinas pró-

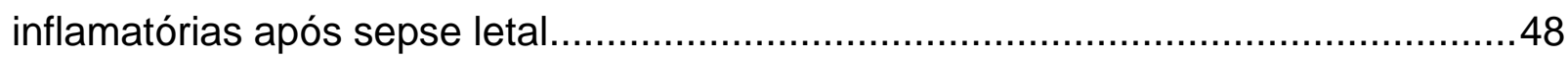

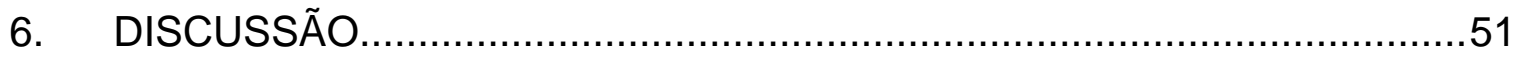

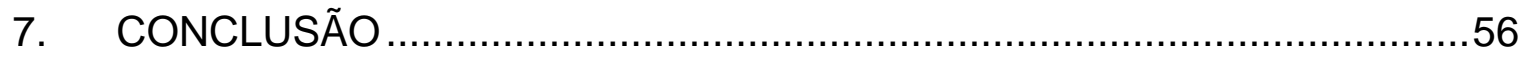

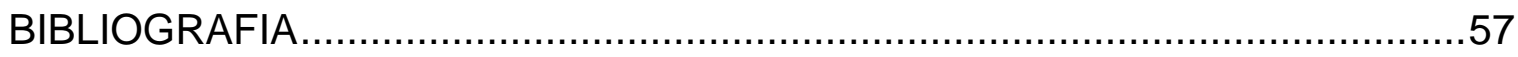




\section{INTRODUÇÃO}

\subsection{DEFINIÇÃO E EPIDEMIOLOGIA DA SEPSE}

Diversos termos e conceitos já foram utilizados para definir o quadro de sepse, havendo uma grande dificuldade para a caracterização do quadro (FUNK; PARRILLO; KUMAR, 2009). Em 1991, houve o primeiro consenso onde o American College of Chest Physicians e a Society of Critital Care Medicine se reuniram com o intuito de caracterizar e definir termos apropriados para auxiliar nos diagnósticos dessa síndrome. Nesse consenso, a sepse ficou definida como uma resposta inflamatória sistêmica (SIRS) decorrente de uma infecção, marcada por um processo de lesão tecidual, onde na fase mais grave, uma síndrome de disfunção de múltiplos órgãos estaria presente (BONE et al., 1992).

O conceito mais atual de sepse foi definido em 2016, quando uma força tarefa de especialistas em terapia intensiva, doenças infecciosas, cirurgiões e especialistas pulmonares foi montada. Esse consenso, batizado de SEPSIS III, trouxe mais clareza e novas definições, além de uma padronização dos critérios de diagnóstico (SINGER et al., 2016). A partir desse consenso a sepse ficou definida como "disfunção orgânica com risco de vida causada por uma resposta desregulada do hospedeiro à infecção" e choque séptico passou a ser definido como "um subconjunto de sepse em que as anormalidades subjacentes do metabolismo circulatório e celular são profundas o suficiente para aumentar substancialmente a mortalidade" (SINGER et al., 2016).

Durante o terceiro consenso de sepse também ficou definida uma padronização no diagnóstico da sepse, denominada avaliação de falência de órgão sequencial (quick Sequential Organ Failure Assessment - qSOFA;) (SINGER et al., 2016). O qSOFA objetivou facilitar o diagnóstico de pacientes com sepse, que é dado através de pontos 
atribuídos a uma série de parâmetros clínicos em que são avaliados a taxa respiratória, coagulação sanguínea, dano hepático, dano renal e dano ao sistema nervoso (Tabela 1) (SINGER et al., 2016). Com isso, o diagnóstico da sepse ficou estabelecido como um quadro clínico de infecção suspeitada ou documentada associada a um score igual ou maior que 2 ou no qSOFA (SINGER et al., 2016).

Tabela 1: Avaliação da falência orgânica sequencial, SOFA (adaptado de Singer et al., 2016)

\begin{tabular}{|c|c|c|c|c|c|}
\hline \multirow{2}{*}{ qSOFA } & \multicolumn{5}{|c|}{ Score } \\
\hline & 0 & 1 & 2 & 3 & 4 \\
\hline $\begin{array}{l}\text { Respiração } \\
\mathrm{PaO} 2 / \mathrm{FIO} 2 \\
\mathrm{mmHg}(\mathrm{kPA})\end{array}$ & $\geq 400(53,3)$ & $<400(53,3)$ & $<300(40)$ & $\begin{array}{c}<200(26,7) \text { com } \\
\text { suporte } \\
\text { respiratório }\end{array}$ & $\begin{array}{c}<100(13,3) \text { com } \\
\text { suporte } \\
\text { respiratório }\end{array}$ \\
\hline 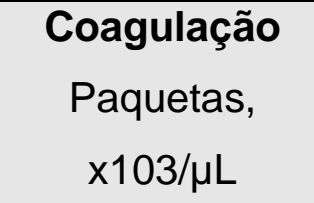 & $\geq 150$ & $<150$ & $<100$ & $<50$ & $<20$ \\
\hline $\begin{array}{c}\text { Fígado } \\
\text { Bilirrubina, } \\
\text { mg/dL } \\
(\mu \mathrm{mol} / \mathrm{L})\end{array}$ & $<1,2(20)$ & $1,2-1,9(20-32)$ & $2,0-5,9(33-101)$ & $6,0-11,9(102-204)$ & $>12,0(204)$ \\
\hline Cardiovascular & PAM $\geq 70 \mathrm{mmHg}$ & $<70 \mathrm{mmHg}$ & $\begin{array}{c}\text { Dopamina }<5 \\
\text { dobutamina }^{\text {a }}\end{array}$ & $\begin{array}{c}\text { Dopamina } 5,1-15 \\
\text { Adrenalina } \leq 0,1 \\
\text { Noradrenalina } \\
\leq 0,1^{\mathrm{a}}\end{array}$ & $\begin{array}{c}\text { Dopamina }>15 \\
\text { Adrenalina }>0,1 \\
\text { Noradrenalina } \\
>0,1^{\mathrm{a}}\end{array}$ \\
\hline $\begin{array}{c}\text { SNC } \\
\text { Escala de coma } \\
\text { de Glasgowb }\end{array}$ & 15 & $13-14$ & $10-12$ & 6-9 & $<6$ \\
\hline $\begin{array}{c}\text { Renal } \\
\text { Creatinina, } \\
\text { mg/dL }(\mu \mathrm{mol} / \mathrm{L})\end{array}$ & $<1,2(110)$ & $1,2-1,9(110-299)$ & $2,0-3,4(171-299)$ & $3,5-4,9(300-440)$ & $>5,0(440)$ \\
\hline Débito urinário, & & & & $<500$ & $<200$ \\
\hline
\end{tabular}




\begin{tabular}{|c|c|c|c|}
\hline ML/d & & & \\
\hline $\begin{array}{l}\text { Abreviações: Fio2, fração inspirada de oxigênio; PAM, pressão arterial } \\
\text { média; PaO2, pressão parcial de oxigênio. }\end{array}$ & $\begin{array}{c}\text { áAs dosagens são dadas como } \mu \mathrm{g} / \mathrm{Kg} / \mathrm{min} \text { por pelo menos uma } \\
\text { hora. }\end{array}$ \\
$\begin{array}{l}\text { bEscala de coma de Glasgow de 3-15;maiores valores desse } \\
\text { score indicam melhor função neurológica. }\end{array}$ \\
\hline
\end{tabular}

Apesar do avanço do conhecimento sobre a fisiopatologia da sepse, a incidência de casos de sepse continua crescendo, fazendo com que a mesma continue sendo um grave problema de saúde pública (RUDD et al., 2020). Além disso, o custo de tratamento de pacientes com sepse é muito elevado. Nos Estados Unidos, o custo é estimado em cerca de 24 milhões de dólares (LIU, VINCENT et al., 2014; TORIO; MOORE, 2006). Já no Brasil, o custo do tratamento por paciente é de cerca de 9.600 dólares (CONDE et al., 2013; NEIRA; HAMACHER; JAPIASSU, 2018).

A sepse e o choque séptico estão entre as maiores causas de morte em unidades de terapia intensiva (UTIs) em todo o mundo, incluindo o Brasil, além disso, a sepse é a décima maior causa de mortes no mundo (SALES JÚNIOR et al., 2006). Estima-se que em 2017 houveram 48,9 milhões de casos de sepse no mundo, havendo sido registradas cerca de 11 milhões de mortes decorrentes da sepse, uma mortalidade de cerca de $22,5 \%$, representando cerca de $19,9 \%$ de todas as mortes ocorridas no ano (RUDD et al., 2020). No Brasil, uma estimativa indica que houveram mais de 185 mil casos de sepse em 2015, com uma mortalidade de mais de $50 \%$ do total de casos (MACHADO et al., 2017; NEIRA; HAMACHER; JAPIASSU, 2018).

\subsection{FISIOPATOLOGIA DA SEPSE}

A falha no controle do patógeno pode ser resultado do balanço de diversas características, podendo ser inerentes ao próprio patógeno, que irão influenciar na sua virulência, ou às características intrínsecas do hospedeiro, as quais afetam a 
capacidade dos mesmos em combater a infecção (STEARNS-KUROSAWA et al., 2011). A eliminação do patógeno pode ser influenciada, por exemplo, pela presença de superantígenos, mecanismos de evasão da resposta imune e a quantidade de microrganismos no foco da infecção. Por outro lado, os fatores relacionados ao hospedeiro, que comprometam o sistema imunológico, também podem desempenhar um importante papel, aumentando a chances do desenvolvimento da sepse, tais como idade, uso de imunossupressores e a apresentação de imunodeficiências e outras comorbidades (ANGUS et al., 2001; RUDD et al., 2020). Esses fatores, juntos, irão contribuir para o avanço da infecção e o subsequente desenvolvimento da sepse.

A sepse pode se originar em decorrência de diversos tipos de infecções, tais como bacterianas, fúngicas, virais ou parasitárias. Contudo, as bactérias representam o maior grupo de agentes etiológicos da síndrome, com incidência semelhante entre bactérias gram-positivas e negativas (NEIRA; HAMACHER; JAPIASSU, 2018; RUDD et al., 2020). Na maioria dos casos, durante uma infecção, o processo infeccioso é resolvido através da resposta imune local. Essa resolução ocorre através do reconhecimento do patógeno por células residentes que iniciam a resposta inflamatória (STEARNS-KUROSAWA et al., 2011). Entretanto, em alguns casos, essa resposta não é adequadamente orquestrada, ocorrendo a disseminação do agente infeccioso através da corrente sanguínea e consequente resposta inflamatória sistêmica, a qual irá resultar em lesão orgânica, originando a sepse. As células lesionadas de tecidos, por sua vez, produzem e secretam padrões moleculares associados a danos (Damage-associated molecular patterns - DAMPs), os quais participam de vias que sinalização que agravam o processo inflamatório (GYAWALI; RAMAKRISHNA; DHAMOON, 2019). 
Para que a resposta contra o patógeno ocorra, é necessário que haja o seu reconhecimento pelas células do hospedeiro, processo que se dá através de receptores de reconhecimento de padrão (pattern recognition receptors - PRRs) (JANEWAY, 2001; MEDZHITOV, RUSLAN, 2007). Os receptores do tipo Toll (Toll-like receptors - TLR) são a classe de PRRs mais bem descrita, presente na membrana celular, os quais são capazes de interagir com vários padrões moleculares associados a patógenos (Pathogen-associated molecular patterns - PAMPs) ou DAMPs, como o lipopolissacarídeo (LPS) de bactérias gram-negativas, os peptideoglicanos de bactérias gram-positivas, bem como outros componentes da parede celular de fungos e ácidos nucleicos, RNA e DNA, tanto do hospedeiro quanto do patógeno (JANEWAY, 2001; TAKEUCHI; AKIRA, 2010). Outro subtipo importante de PRRs são os inflamassomas, diversas classes de inflamassomas foram descritas, como os receptores semelhantes a NOD (NOD-like receptor - NLRP) e o ausente no melanoma (absent in melanoma 2 AIM2), diversas moléculas são conhecidas por ativar inflamassomas, como LPS citosólico e DNA, a ativação desses receptores, induz a ativação das caspases 1 e 11, que irão induzir clivagem das citocinas inflamatórias IL-1ß e IL-18 para suas formas ativas.

A ativação dos PRRs irá gerar a transdução de sinais culminando na fosforilação e ativação de proteínas kinase ativada por mitógeno (MAPKs), Janus kinases (JAKs), STATs (signal transducers and activators of transcription), ou a translocação nuclear do fator nuclear kB (NF-kB) e do fator regulador de interferon (IRF). Esse processo irá resultar na produção de citocinas inflamatórias, como o fator de necrose tumoral (TNF), interleucina (IL)-1, IL-12, IL-18 e interferons (IFN) do tipo 1 (JANEWAY; MEDZHITOV, 2002; MEDZHITOV, RUSLAN, 2007). Além disso, há também a produção de 
quimiocinas, moléculas que irão auxiliar na ativação e migração de leucócitos para o local da infecção, participando da eliminação do patógeno (JANEWAY; MEDZHITOV, 2002; MEDZHITOV, RUSLAN, 2007).

Durante a sepse há um descontrole da resposta inflamatória, em que há a presença excessiva de PAMPs e DAMPs. A ativação constante dos PRRs por PAMPs irá gerar uma grande produção de citocinas e quimiocinas, desencadeando uma resposta inflamatória sistêmica (BOSMANN; WARD, 2013; HOTCHKISS et al., 2016). Essa inflamação exacerbada irá causar danos às células do hospedeiro, resultando na liberação de DAMPs, o que irá potencializar a resposta inflamatória. Além disso, mediadores anti-inflamatórios, como IL-10, IL-4 e IL-13, também podem ser liberados devido à resposta inflamatória exacerbada (BOSMANN; WARD, 2013; HOTCHKISS et al., 2016).

\subsection{RECEPTORES DE DNA NA SEPSE}

Estudos recentes sugerem que o DNA, tanto do patógeno quanto do hospedeiro, pode ser um importante componente da fisiopatologia de diversas doenças, podendo ativar PRRs, resultando na produção de mediadores inflamatórios que podem contribuir significativamente para o processo patológico (MARSMAN; ZEERLEDER; LUKEN, 2016; STEWART et al., 2018). Diversos estudos recentes vêm mostrando que receptores de ácidos nucleicos, como TLR9 e estimulador de genes de interferon (stimulator of interferon genes - STING), estão diretamente envolvidos na fisiopatologia da sepse em modelos animais contribuindo para a gravidade da mesma (GAO et al., 2012; HEIPERTZ; HARPER; WALKER, 2017; PLITAS et al., 2008).

O TLR9 é um importante PRRs responsável pelo reconhecimento de ácidos nucleicos, expresso intracelularmente, dentro dos compartimentos endossômicos, 
podendo ser encontrado também na membrana celular, esse receptor reconhece DNA rico em motivos CpG, presente no genoma de bactérias e na mitocôndria. Uma vez ativado, mudanças conformacionais no TLR9 resultam no recrutamento de proteínas adaptadoras contendo o domínio TIR, como MyD88, que iniciam as vias de transdução de sinal que culminam na ativação de NF-KB e IRF7 quinases responsáveis por regular a expressão de citocinas. Portanto, o reconhecimento de DNA pelo TLR9 leva à ativação das células, iniciando reações que resultam na produção de citocinas, como IFN tipo 1, IL-6, TNF e IL-12 (ROERS; HILLER; HORNUNG, 2016).

A ativação excessiva de TLRs está diretamente associada ao agravamento da sepse, contribuindo significativamente para sua fisiopatologia. Plitas, et al (2008) demonstraram que a ativação de TLR9 está envolvida com o agravamento da sepse em camundongos, onde animais deficientes em TLR9 apresentavam uma taxa de sobrevida aumentada comparada aos animais selvagens. Posteriormente, Trevelin, et al (2012) demonstraram que a ativação de TLR9 em modelo de sepse está amplamente relacionada à falha na migração de neutrófilos ao foco infeccioso primário. A ativação de TLR9 induz a expressão e ativação de GRK2, induzindo, por sua vez, a dessensibilização de CXCR2. Além disso, ocorre também a indução da expressão de CCR2, favorecendo o recrutamento de neutrófilos aos órgãos que apresentam expressão de CCL2, o que acarreta lesões teciduais (TREVELIN et al., 2012).

Outro importante receptor de reconhecimento de DNA é a via cGAS-STING. O STING é uma importante molécula sinalizadora, presente no citoplasma, em que sua ativação resulta na produção de interferons do tipo I. Sua via começa através do reconhecimento de DNA dupla fita citoplasmático através do GMP- AMP cíclico (cGAMP) sintetase (cGAS) produzindo o segundo mensageiro cGAMP que, por sua 
vez, irá ativar o receptor STING que irá translocar para o complexo de Golgi, ativando o IRF3 e NF-KB (AHN; BARBER, 2014; BURDETTE et al., 2011). A ativação da via cGASSTING resulta na produção de citocinas pro-inflamatórias, como IFN tipo 1, IL-6, TNF e IL-12.

Estudos recentes vêm demonstrando a importância da via no contexto da sepse. Heipertz e colaboradores (2017) demonstraram que animais deficientes para STING e, também para IRF3 apresentaram uma maior taxa de sobrevivência na sepse letal, bem como melhora no score clínico desses animais, além de apresentarem um menor nível de citocinas proinflamatórias, contudo, essa melhora não foi observada na sepse moderada (HEIPERTZ; HARPER; WALKER, 2017). O STING também parece estar envolvido na proteção cardíaca após a endotoxemia, através da redução significativa da morte de cardiomiócitos, via regulação do inflamassoma NLRP3, reduzindo a piroptose dessas células. Além disso, aumentou a sobrevida e melhorou a função cardíaca do grupo de animais submetidos à endotoxemia por LPS (LI et al., 2019).

Os inflamassomas são importantes PRRs que também estão correlacionados à fisiopatologia da sepse. AIM2 é um sensor citoplasmático que reconhece DNA dupla fita de origem microbiana ou do hospedeiro. Ao se ligar ao DNA, o AIM2 monta um complexo multiproteico denominado inflamassoma, que conduz a piroptose, um tipo de morte celular, e clivagem proteolítica das citocinas pró-inflamatórias pró-IL-1ß e pró-IL18 em suas formas ativas (MAN; KARKI; KANNEGANTI, 2016). Esse receptor já foi descrito por possuir um importante papel em doenças inflamatórias, como artrite e psoríase (MAN; KARKI; KANNEGANTI, 2016). Contudo, pouco se sabe acerca do seu papel na fisiopatologia da sepse, portanto, mais estudos são necessários para elucidálo. Outros tipos de inflamassomas, como o NLRP3, já foram descritos como importantes 
componentes da fisiopatologia da sepse, uma vez que animais deficientes para NLPR3 são mais resistentes à sepse, com menor produção de mediadores lipídicos proinflamatórios e maior produção de lipoxina B4, um mediador lipídico resolutivo (LEE et al., 2017).

\subsection{PAPEL DOS NEUTRÓFILOS NA SEPSE}

Durante a resposta inflamatória, os neutrófilos são os primeiros leucócitos a serem recrutados para o foco da inflamação desempenhando um papel importante no controle de infecções, devido a um grande estoque de grânulos que armazenam enzimas proteolíticas e citotóxicas, além de a capacidade de rápida produção de espécies reativas de oxigênio (MEDZHITOV, R.; JANEWAY C., 2000). A migração dessas células durante o processo inflamatório é dividida em quatro etapas: marginação, rolamento, adesão e transmigração (SHEN et al., 2017). O processo de marginação ocorre a partir da indução da expressão de selectinas nas células que participam do processo, como consequência da interação das mesmas com os mediadores inflamatórios produzidos por células residentes. A expressão de selectinas tanto nos leucócitos (L-selectinas) quando no endotélio vascular (E-selectinas) possibilitará a interação entre essas células, dando início ao processo de rolamento (SHEN et al., 2017). Durante esse processo ocorre a ativação dos leucócitos através das quimiocinas que resulta na interação com as integrinas, possibilitando o aumento da adesão dos neutrófilos as células endoteliais. Depois de aderidos, os neutrófilos respondem ao gradiente quimiotático, completando o processo de transmigração (KOVACH; STANDIFORD, 2012; SHEN et al., 2017).

A migração eficiente de neutrófilos para um foco infeccioso é um dos eventos mais importantes para evitar que os microrganismos presentes no local da infecção se 
disseminem para a circulação desencadeando e/ou agravando a sepse. Em quadros de sepse, ocorre falência da migração desse subtipo celular para o foco infeccioso, contribuindo para a proliferação e disseminação bacteriana (ALVES-FILHO, et al., 2005; BENJAMIM; FERREIRA; CUNHA, 2000). Investigando os mecanismos envolvidos nessa falência, foi demonstrado que a dessensibilização de CXCR2, um receptor de quimiocinas envolvido na migração de neutrófilos, é um dos mecanismos centrais responsáveis por essa falha (ALVES-FILHO, et al., 2009; SHEN et al., 2017; ZHANG et al., 2016). O processo de dessensibilização do CXC2 em neutrófilos ocorre devido a elevada ativação de TLRs nessas células, que irão promover a ativação de GRK2, induzindo a internalização do receptor CXCR2 (SÔNEGO et al., 2016).

Além dos mecanismos de fagocitose e de degranulação, os neutrófilos possuem um outro mecanismo para eliminação de microrganismos, descrito por BRINKMANN e colaboradores (2004). Esse mecanismo consiste na liberação de redes de DNA decoradas com histonas e proteínas, como a mioloperoxidase (MPO), elastase dos neutrófilos e PAD4 (peptidil arginina deiminase 4) que compõe o arcabouço de produção e liberação das NETs, (do inglês, neutrophil extracelular traps) (PAPAYANNOPOULOS, 2018). As NETs possuem a capacidade de imobilizar e matar microrganismos devido à alta concentração de agentes citotóxicos, capazes de eliminar uma grande variedade de patógenos, como bactérias gram-positivas e gram-negativas, fungos, vírus e protozoários (BRINKMANN et al., 2004; GUIMARÃES-COSTA et al., 2009; HIROKI et al., 2020; URBAN et al., 2006).

Essas redes são formadas a partir da ativação da enzima proteína peptidil arginina deiminase 4 (PAD-4) presente em granulócitos (PAPAYANNOPOULOS, 2018)que é ativada por um mecanismo dependente do aumento do influxo de cálcio, 
sua ativação irá levar a citrulinação das histonas, resultando na descondensação da cromatina (WANG et al., 2009). A progressão para a NETose inclui a descondensação da cromatina, translocação nuclear da elastase, desintegração do envelope nuclear, formação de um vacúolo intracelular que mistura DNA e conteúdo granular, seguido de extrusão através da membrana plasmática (THIAMA et al., 2020).

Estudos anteriores do nosso grupo demonstraram que as NETs estão diretamente correlacionadas com a lesão de órgãos durante a sepse. Czaikoski e colaboradores (2016) demonstraram que a depleção das NETs com DNAse, concomitante ao tratamento com antibiótico, aumentou a sobrevida e diminuiu a lesão de órgãos de camundongos submetidos ao modelo de sepse letal. Já Colon e colaboradores (2019) demonstraram que as NETs estão envolvidas na lesão orgânica em quadro de sepse em infantes e que o tratamento com Cl-amidina, um inibidor de PAD-4, combinado ao antibiótico, elevou significativamente a sobrevida de camundongos infantes submetidos à sepse. Sendo assim, as NETs desempenham um importante papel na lesão de órgãos associadas à sepse.

\subsection{DNA PLASMÁTICO NA SEPSE}

Moléculas de DNA livre de células (cfDNA) foram descobertas no sistema circulatório humano em 1948 (MANDEL; METAIS, 1948). As principais fontes de cfDNA são a morte celular, seja por necrose ou apoptose, e a liberação ativa por células, incluindo exocitose e NETose (MAGNA; PISETSKY, 2016). Além disso, os cfDNA podem derivar do DNA nuclear (nDNA), mitocondrial (mDNA) ou bacteriano (bDNA) (HAMAGUCHI et al., 2015). Inicialmente, pouco se sabia sobre a importância do cfDNA, acreditando-se que sua presença no plasma era irrelevante, contudo, sua importância clínica vem sendo reconhecida devido a diferenças entre as concentrações de cfDNA 
de indivíduos saudáveis e doentes. Atualmente, concentrações aumentadas de cfDNA são consideradas biomarcadores de gravidade para pacientes com diversos tipos de doenças, incluindo doenças autoimune, câncer e sepse (BRONKHORST; UNGERER; HOLDENRIEDER, 2019; DUVVURI; LOOD, 2019; RHODES; CECCONI, 2012).

O DNA extracelular possui grande importância como biomarcador da gravidade da sepse, bem como um importante papel na fisiopatologia da síndrome. Além disso, diversos estudos vêm demonstrando que os receptores de ácidos nucleicos possuem, também, um importante papel na fisiopatologia da doença, contudo, os mecanismos pelo qual esses receptores são ativados e se o DNA extracelular possui um papel importante na ativação desses receptores ainda não está bem elucidado. Portando, fazse necessário uma melhor investigação acerca dos mecanismos através dos quais o DNA extracelular contribui para fisiopatologia da sepse.

Uma característica comum observada em pacientes com sepse é a alta concentração de DNA extracelular no plasma. Diversos estudos têm encontrado associação entre os níveis de DNA extracelular e o agravamento do quadro clínico, correlacionando danos aos órgãos distantes do foco infeccioso à morte desses pacientes (DWIVEDI et al., 2012; SAUKKONEN et al., 2008). Dwivedi e colocaboradores (2012) demonstraram que os níveis de DNA extracelular estão diretamente correlacionados com o SOFA em pacientes com sepse, servindo como um importante preditor do quadro clinico dos mesmos. Além disso, estudos utilizando modelos de sepse em camundongos demonstraram que o cfDNA presente no plasma de animais sépticos é, em sua maioria, proveniente do próprio hospedeiro (HAMAGUCHI et al., 2015; LAUKOVÁ et al., 2019). 


\section{HIPÓTESE}

O DNA extracelular possui grande importância como biomarcador de gravidade da sepse, bem como um importante papel na fisiopatologia da síndrome. Além disso, diversos estudos vêm demonstrando que os receptores de ácidos nucleicos, possuem também um importante papel na fisiopatologia da doença. Sendo assim, a hipótese do nosso trabalho é que o DNA extracelular leva à ativação de receptores de DNA em neutrófilos, induzindo a formação de NETs e contribuindo para a inflamação e lesão de órgãos na sepse. 


\section{OBJETIVOS}

\subsection{Objetivo Geral}

Avaliar se a ativação de receptores de DNA, STING, TLR9 e AIM2, contribuem para a produção de NETs na sepse.

\subsection{Objetivos Específicos}

- Avaliar a cinética da concentração do DNA plasmático no modelo de CLP;

- Verificar se a ativação de STING induz a produção de NETs;

- Avaliar a se a deficiência de STING na CLP, altera a sobrevida, a produção de NETs, a extensão da lesão orgânica e a produção de citocinas; 


\section{MATERIAL E MÉTODOS}

\section{1. $\quad$ ANIMAIS}

Foram utilizados camundongos machos ou fêmeas de 6-8 semanas: C57BL6 selvagens (originados do Biotério Central da Faculdade de Medicina de Ribeirão PretoFMRP-USP); deficientes em TLR9, TLR9--(originados Centro de Criação de Camundongos Especiais, Departamento de Genética, FMRP-USP); , deficientes em STING, STING-- (obtidos do Jackson Laboratory, EUA, criados e mantidos no biotério da clínica médica); deficientes em AIM2, AIM2--- (obtidos do biotério do Departamento de Imunologia, FMRP-USP). Os animais foram mantidos no biotério do Departamento de Farmacologia, FMRP-USP, sob condições controladas de ciclo claro/escuro, umidade e temperatura, além de alimentação ad libitum. Os animais ficaram em cohouse por, pelo menos, 3 semanas para pareamento da microbiota. Os experimentos foram aprovados e conduzidos de acordo com o comitê de ética de animais de experimentação da Faculdade de Medicina de Ribeirão Preto (número de registro: 126/2019).

\subsection{MODELO DE SEPSE}

Os animais foram anestesiados com anestésico inalatório (isoflurano 1,5\%) e, em seguida, foi realizada tricotomia e desinfecção com álcool-iodado da região abdominal. Posteriormente, foi realizada incisão de $1 \mathrm{~cm}$ no abdômen para ter-se acesso à cavidade peritoneal e ao ceco. O conteúdo cecal foi movido gentilmente para a porção distal do ceco, em seguida, o conteúdo foi aprisionado utilizando uma ligadura, com linha de algodão. Após esse procedimento, duas perfurações com uma agulha de calibre de $18 \mathrm{G}$ foram realizadas no ceco dos animais para indução da sepse letal. 0 ceco foi, então, pressionado gentilmente para saída do conteúdo cecal através das 
perfurações e colocado de volta no interior da cavidade abdominal e, finalmente, a incisão foi suturada. Após a cirurgia, foi administrado $1 \mathrm{~mL}$ de solução salina por via subcutânea, para hidratação, além de tramadol $(12,5 \mathrm{mg} / \mathrm{kg})$, a cada 12 horas, por 3 dias. Além disso, para manter os animais aquecidos durante a recuperação da cirurgia, nesse período, os mesmos foram mantidos em ambiente aquecido por luz incandescente. Animais pertencentes ao grupo sham foram submetidos à cirurgia, porém não tiveram o ceco perfurado. Após os procedimentos, os animais foram novamente acondicionados no biotério departamental. $\mathrm{O}$ acompanhamento da mortalidade foi realizado a cada $12 \mathrm{~h}$, durante 8 dias.

\subsection{COLETA DE CÉLULAS DO SANGUE E PLASMA}

Os animais foram submetidos a eutanásia com injeção intravenosa de ketamina (100 mg.kg-1) e xilasina (10 mg.kg-1), através do plexo orbital, juntamente com $10 \mathrm{uL}$ de heparina. Após certificação da morte do animal, o sangue foi coletado através de punção do plexo orbital utilizando capilar com 30 uL de EDTA. O plasma foi separado dos outros hemocomponentes através de centrifugação (1000g, 10 minutos, $4^{\circ} \mathrm{C}$ ), coletado e condicionado até análise à $-70^{\circ} \mathrm{C}$. As células que ficaram separadas do plasma foram ressuspendidas em solução de Tris-Cloreto de amônio (Hudson et al, 1989) para a lise de hemácias e, em seguida, utilizadas para citometria e contagem total utilizando câmara de Neubauer.

\subsection{COLETA DO LAVADO PERITONEAL}

Após a eutanásia, foi injetado 1,5 mL de PBS contendo $1 \mathrm{mM}$ de EDTA na cavidade peritoneal, posteriormente à homogeneização através de leve massagem no abdômem, o lavado foi recuperado. O lavado foi, então, centrifugado (450g, 5 minutos, $4^{\circ} \mathrm{C}$ ) para coleta do sobrenadante, que foi acondicionado em $-70^{\circ} \mathrm{C}$ até a realização da 
quantificação de citocinas e quimiocinas. O pellet, que contem células, foi submetido a lise de hemácias e, em seguida, as células brancas remanescentes foram utilizadas para citometria e contagem total com a utilização de câmara de Neubauer.

\subsection{CONTAGEM BACTERIANA}

Amostras de sangue e lavado peritoneal foram coletadas após a CLP e diluídas para quantificação de bactérias viáveis. No caso do lavado peritoneal, as diluições foram de 1:100, 1:1000, e 1:10000, já o sangue foi plaqueado puro ou na diluição de 1:10. As diluições foram semeadas em placas de Petri contendo meio Agar MüllerHinton (Difco Laboratories) e incubadas a $37^{\circ} \mathrm{C}$ por 18 horas. O número de unidades formadoras de colônias (UFC) foi registrado e considerado equivalente ao número de bactérias viáveis nas amostras avaliadas. Os resultados foram expressos em Log de UFC por $\mathrm{mL}(\mathrm{UFC} / \mathrm{mL})$.

\subsection{DETERMINAÇÃO DOS NÍVEIS DE CITOCINAS}

Após coleta do lavado peritoneal, plasma e tecidos, as concentrações de citocinas e quimiocinas foram determinadas através de ensaio imunoenzimático (ELISA), seguindo o protocolo do fabricante (R\&D Systems, Minneapolis - USA). Brevemente, o método consistiu no coating de anticorpos de captura em placa de 96 poços durante $12 \mathrm{~h}$ em refrigeração de $4^{\circ} \mathrm{C}$, em seguida, de lavagem dos anticorpos não ligados à placa com PBS-Tween (Sigma Aldrich - USA); bloqueio de ligações

inespecíficas com PBS com 0,5\% BSA (Sigma Aldrich - USA) por 2h em temperatura ambiente; lavagem; adição de (50 uL) amostras a serem quantificadas e controles: curva de calibração e um poço com ausência de amostra (incubação por $2 \mathrm{~h}$ em temperatura ambiente); lavagem; adição do anticorpo de detecção (incubação por $2 \mathrm{~h}$ em temperatura ambiente); lavagem; adição de solução $1 \mathrm{X}$ de estreptoavidina por 30 
minutos em temperatura ambiente; lavagem; adição de substrato colorimétrico TMB (tetrametilbenzidina; Sigma); e solução para inibição da reação, H2SO4 (1 M). As absorbâncias foram lidas em equipamento de espectrofotometria em comprimento de onda de 450 nm (Spectra Max-250, Molecular Devices). As concentrações de citocinas e quimiocinas foram expressas em picogramas por $\mathrm{mL}(\mathrm{pg} / \mathrm{mL})$ ou em nanogramas por $\mathrm{mL}(\mathrm{ng} / \mathrm{mL})$.

\subsection{EXTRAÇÃO DE DNA}

O sangue total foi colhido de cada animal por punção do plexo orbital sob anestesia e transferido para tubos de EDTA. Para explorar a dinâmica do DNA extracelular plasmático sob condições sépticas, o plasma foi coletado em 3, 6, 12 e 24 horas após a operação CLP de todos os camundongos. O plasma foi separado por centrifugação a $1000 \mathrm{~g}$ durante 10 minutos e, imediatamente, congelado a $-80^{\circ} \mathrm{C}$ para extração do DNA plasmático. O DNA plasmático foi extraído através do kit QIAamp DNA Blood Mini Kit (Qiagen, Hilden, Germany) conforme o protocolo do fabricante. A concentração de DNA extraído do plasma dos animais foi quantificada através do NanoDrop ${ }^{\text {TM }}$ One/OneC (Thermo Scientific).

\subsection{PURIFICAÇÃO DE NEUTRÓFILOS}

Foi obtida a medula óssea de fêmures e tíbias de camundongos C57BL/6 WT e $\mathrm{STING}^{-1}$. Após eutanásia, a medula óssea foi coletada através de flushing do conteúdo medular do fêmur e tíbia. Ass hemácias foram, então, lisadas, e os leucócitos resuspendidos em meio Hanks (Sigma-Aldrich), na quantidade de $2 \mathrm{~mL}$ por cada animal. As suspensões de célulasforam cuidadosamente pipetadas em um gradiente de Percoll (Sigma-Aldrich) de concentrações $72 \%$ e $65 \%$ montadas uma sobre a outra, maior 
concentração para a menor, em um tubo de poliestireno de $15 \mathrm{~mL}$. Os gradientes foram centrifugados por 30 minutos, a $500 \mathrm{~g}$, temperatura de $4^{\circ} \mathrm{C}$. Logo, as células polimorfonucleares, presentes entre os gradientes de $72 \%$ e $65 \%$, foram separadas e lavadas com meio Hanks, ressuspendidas em meio RPMI-1640 suplementado com $0.1 \%$ de BSA (Sigma-Aldrich) e contadas em câmara de Neubauer. Para avaliação da pureza, foi feito um citospin, os quais foramcoradas com corante Panótico Rápido (Interlab) e avaliadas em microscópio.

\subsection{INDUÇÃO DE NETS IN VITRO}

Foram plaqueados $1 \times 10^{6}$ neutrófilos em placa de 48 poços. Oss neutrófilos foram estimulados com PMA (100 nM), DMXAA $(5 \mu \mathrm{M}), \mathrm{nDNA}(5 \mu \mathrm{g} / \mathrm{mL}), \mathrm{mtDNA}(5 \mu \mathrm{g} / \mathrm{mL}) \mathrm{e}$ bacDNA $(5 \mu \mathrm{g} / \mathrm{mL})$ e incubados por 4 horas em estufa de $\mathrm{CO}_{2}$ à $37^{\circ} \mathrm{C} 5 \% \mathrm{CO}_{2}$. Após a incubação, o sobrenadante da cultura foi coletado e armazenads em freezer $-20^{\circ} \mathrm{C}$ para posterior dosagem de NETs.

\subsection{QUANTIFICAÇÃO DE NETS}

Para avaliar a produção de NETs em sobrenadantes de culturas ou em amostra de plasma murinho, foi utilizado o método MPO-DNA PicoGreen. Brevemente, foi utilizada uma placa Black Plate Clear Botton (Sigma-Aldrich) para realizar o coating com anti-MPO (1:100, ThermoFisher), overnight à $4^{\circ} \mathrm{C}$. A placa foi lavada em solução de PBS-Tween $0,5 \%$ e incubada com as amostras, overnight à $4^{\circ} \mathrm{C}$. Após nova lavagem., foi adicionado o reagente fluorescente Quant-iT ${ }^{\mathrm{TM}}$ PicoGreen $^{\mathrm{TM}}$ dsDNA assay Kit (Invitrogren), conforme o protocolo do fabricante e, em seguida, foi feita a leitura dos dados no aparelho FlexStatiton® 3, com excitação a 488nm e leitura a 525nm. 


\subsection{ANÁLISE ESTATÍSTICA}

Os resultados foram expressos como média \pm erro padrão da média (EPM) obtidos em 3 experimentos independentes. A comparação da média entre diferentes grupos foi realizada pela análise de variância (ANOVA). A contagem bacteriana foi analisada pelo teste Mann-Whitney. A sobrevida dos grupos foi expressa como percentagem e a diferença estatística determinada pelo teste Mantel-Cox logrank. Os dados foram analisados utilizando GraphPad Prism (GraphPad Software, USA). 


\section{RESULTADOS}

\subsection{Aumentadas concentrações de DNA livre plasmático são}

encontradas em estímulos sépticos de diferentes intensidades

A sepse é marcada por altas concentrações de DNA plasmático, estudos recentes mostraram que os níveis de DNA plasmático podem ser associados com a severidade da sepse (DWIVEDI et al., 2012; SAUKKONEN et al., 2008). Inicialmente investigamos se os níveis de DNA plasmático estão aumentados em diferentes graus de gravidade no modelo de sepse induzida por CLP. Inicialmente, as curvas de sobrevida foram construídas e experimentos posteriores foram realizados por meio de coleta de sangue nos diferentes tempos: 3, 6, 12 e 24 horas após a indução da sepse, para avaliação das cinéticas de elevação da bacteremia, DNA plasmático e NETose nos dois modelos empregados. Os animais submetidos ao modelo de sepse moderada (CLP-M) apresentaram uma sobrevida de $50 \%$, com todos os eventos de morte ocorridos até o terceiro dia, já no modelo de sepse letal (CLP-L) todos os animais morreram até o terceiro dia (Figura 1A). Ao analisar a quantidade de unidades formadoras de colônia bacteriana por mililitro de sangue desses animais, identificamos que animais submetidos ao modelo de sepse moderada apresentam redução da bacteremia, ao passo que, na sepse letal ocorre aumento progressivo do número de bactérias no sangue (Figura 1B). A análise do DNA livre circulante demonstrou que os animais submetidos a CLP-M e CLP-L apresentaram aumento no total de DNA no plasma, com pico após 12h da indução da sepse, o qual persiste apenas no grupo submetido à CLP-L (Figura 1C). Além disso, avaliamos também a concentração de NETs nos modelos de sepse empregados neste estudo. Os nossos resultados indicam que tanto os animais submetidos ao modelo de sepse moderada quanto ao letal 
apresentam aumento na concentração plasmática de NETs a partir das 6 h após a indução da sepse. Conforme esperado, os animais com sepse letal possuem as maiores concentrações quando comparados ao grupo com sepse moderada (Figura 1D). Com base nos resultados observados, identificamos que o modelo de sepse letal é mais eficiente na elevação dos níveis de DNA plasmático e NET, sugerindo que a elevação desses marcadores no nosso modelo animal, conforme demonstrado na clínica (DWIVEDI et al., 2012; SAUKKONEN et al., 2008), possa ser associada com a gravidade da doença Para a garantia de resultados mais consistentes, optamos pelo uso do modelo de CLP-letal nos experimentos posteriores. 
A

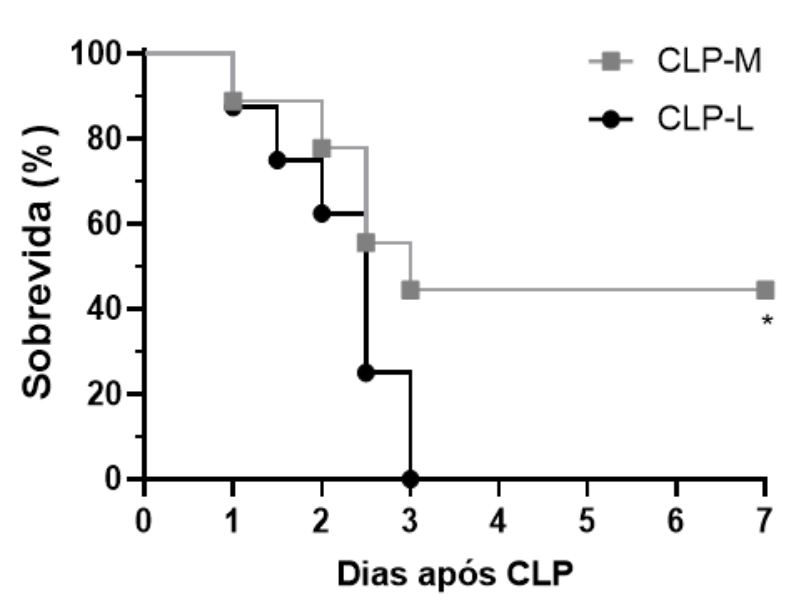

C

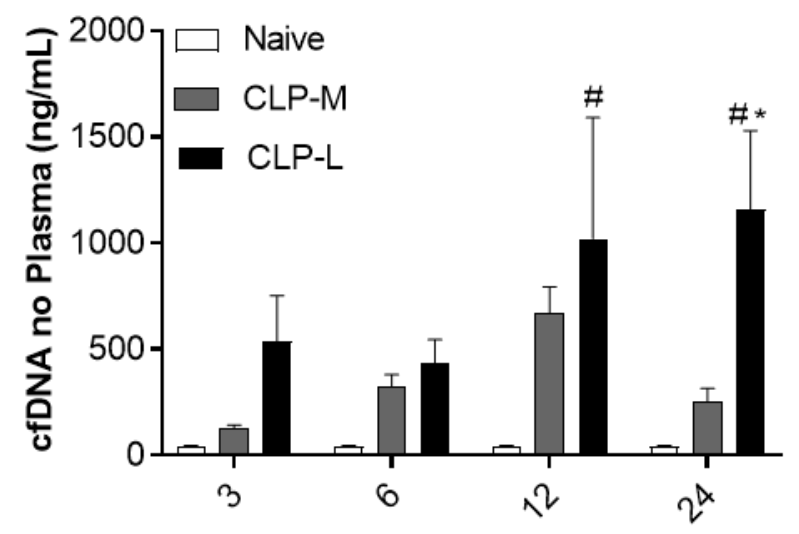

Horas após CLP
B

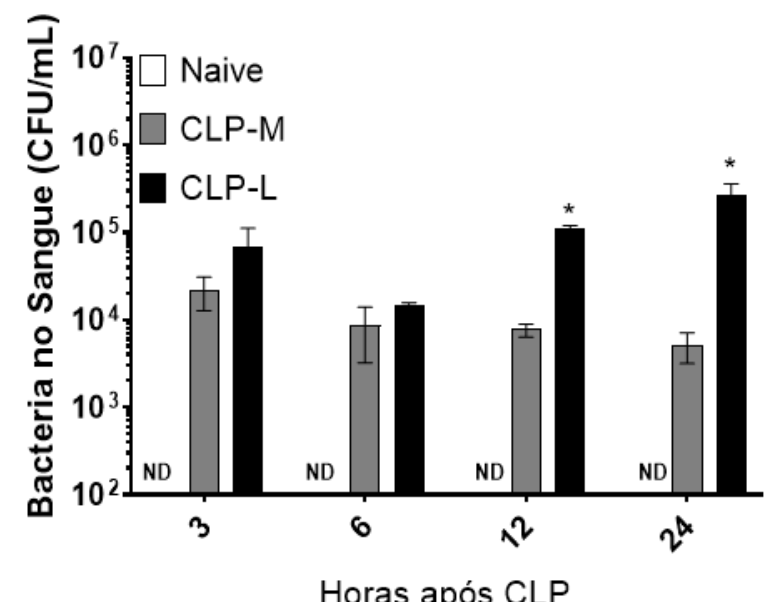

Horas após CLP
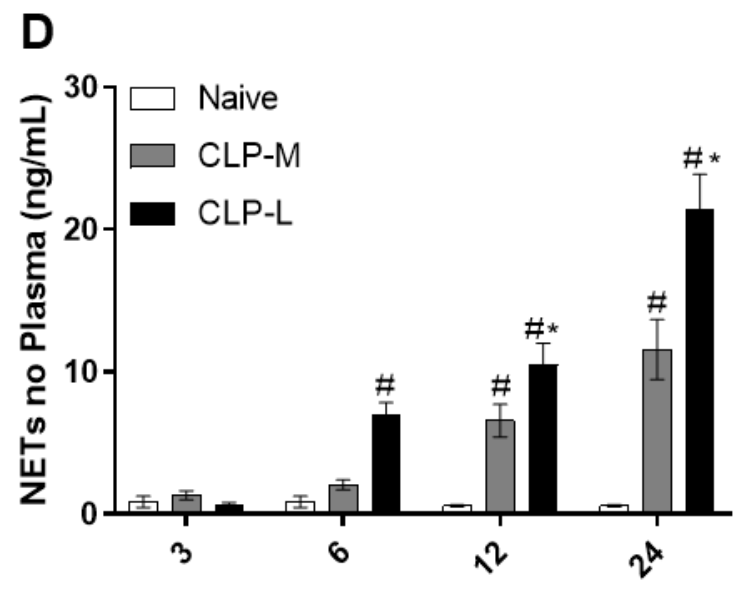

Horas após CLP

Figura 1. Camundongos submetidos à CLP-M e CLP-L possuem aumento na concentração de cfDNA e NET plasmático. Animais selvagens foram submetidos a diferentes intensidades de sepse CLP-M e CLP-L; (A) A Sobrevida dos animais submetidos à CLP-M e CLP-L foi observada por 7 dias. (B) As unidades formadoras de colônia (UFC) foram quantificadas no sangue coletado após 3, 6, 12 e 24 horas da indução da sepse. Os dados estão expressos como o número de UFC por mililitro de sangue (UFC/mL). (C) A concentração de cfDNA foi quantificada no plasma coletado após 3, 6, 12 e 24 horas da indução da sepse. Os dados estão expressos em ng por mililitro de plasma ( $\mathrm{ng} / \mathrm{mL}$ ). (D) A concentração de NETs foi quantificada no plasma coletado após 3, 6, 12 e 24 horas da indução da sepse. Os dados estão expressos em ng por mililitro de plasma $(\mathrm{ng} / \mathrm{mL})$. A avaliação da diferença na curva de sobrevida foi 
analisada utilizando o teste Mantel-Cox logrank (nível de significância: $p<0,05$ ). Os demais resultados foram analisados por ANOVA seguida pelo teste de Newman-Keuls e expostos como média \pm E.P.M ( ${ }^{*}$ representa a comparação entre os grupos CLP-M e CLP-L em que $p<0,05$. \# representa a comparação com o grupo Naive em que $p<0,05$ ).

\subsection{Neutrófilos estimulados com diferentes tipos de DNA induzem a formação de NETs}

Um estudo recente demonstrou que o DNA mitocondrial é capaz de induzir NETs por meio da ativação de STING, um importante sensor de DNA (LIU, et al., 2019). Após demonstrar que o DNA plasmático está correlacionado com a gravidade da sepse e sabendo que o DNA mitocondrial é capaz de induzir NETs, nos perguntamos se a ativação de STING com diferentes tipos de DNA poderia estar induzindo a produção de NETs in vitro através de STING. Primeiramente, avaliamos se a ativação de STING com o agonista DMXAA seria capaz de induzir a produção de NETs in vitro e verificamos que a ativação de STING com DMXAA foi capaz de induzir a produção de NETs de forma concentração dependente (Figura 2A). Posteriormente, analisamos se diferentes tipos de DNA eram capazes de induzir a produção de NETs, e observamos que todos os tipos de DNA analisados foram capazes de induzir NET. 

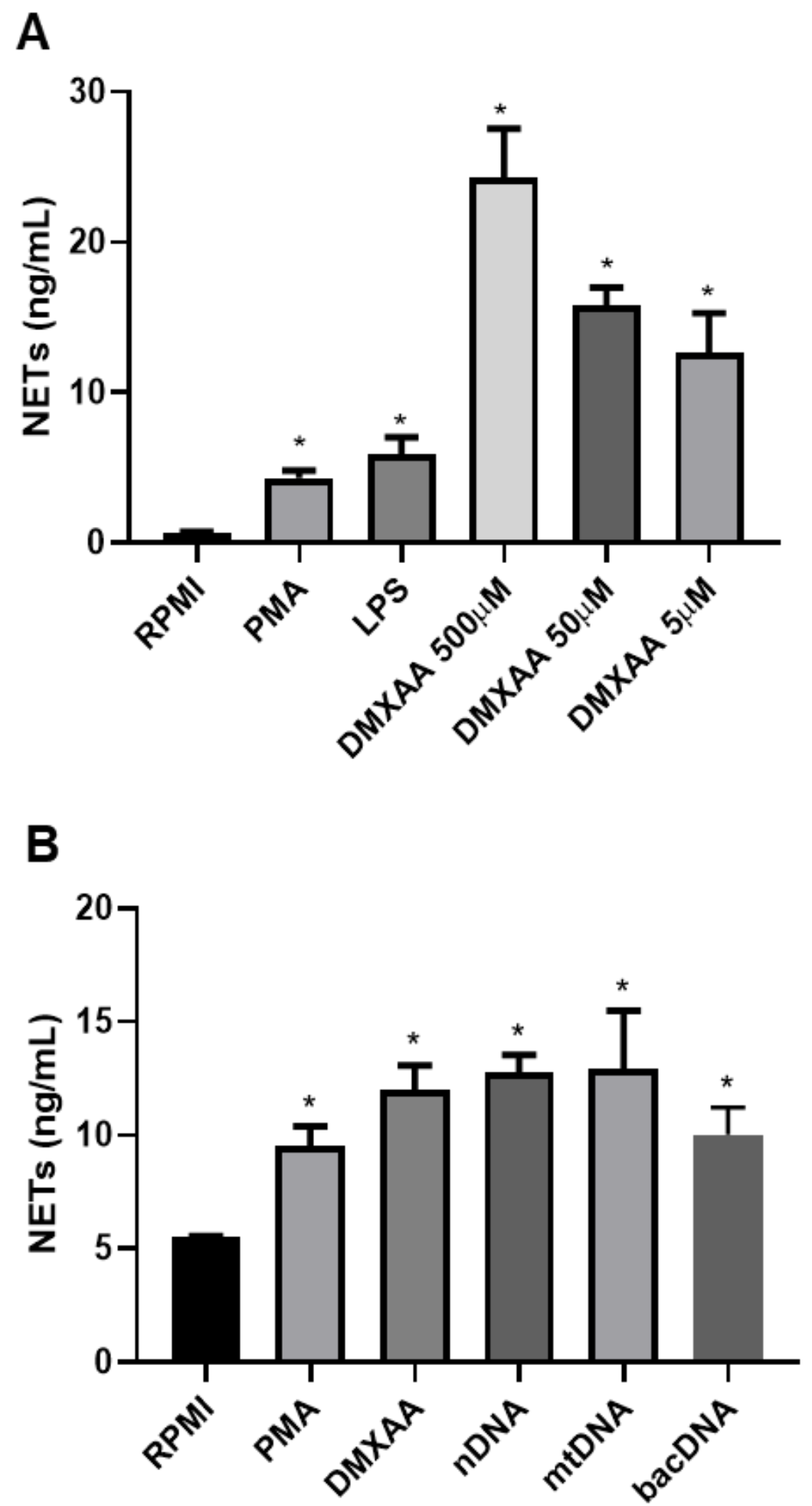

Figura 2. Estímulos de neutrófilos com diferentes tipos de DNA induzem a formação de NETs. (A) Neutrófilos isolados da medula óssea de camundongos 
selvagens foram estimulados com PMA (100 nM), LPS $(10 \mathrm{mg} / \mathrm{mL})$ e DMXAA $(500,50$ e $5 \mu \mathrm{M}$ ) durante 4 horas e avaliados quanto a produção de NETs. Os dados estão expressos em $\mathrm{ng}$ por mililitro $(\mathrm{ng} / \mathrm{mL})$; (B) Neutrofilos isolados da medula óssea de camundongos selvagens foram estimulados com PMA (100 nM), DMXAA $(5 \mu \mathrm{M})$, DNA nuclear (nDNA - $5 \mathrm{mg} / \mathrm{mL}$ ), DNA mitocondrial ( $\mathrm{mtDNA}-5 \mathrm{mg} / \mathrm{mL}$ ) e DNA bacteriano (bacDNA - $5 \mathrm{mg} / \mathrm{mL}$ ) durante 4 horas e avaliados quanto a produção de NETs Os dados estão expressos em $\mathrm{ng}$ por mililitro $(\mathrm{ng} / \mathrm{mL})$. Os resultados foram analisados por ANOVA seguida pelo teste de Newman-Keuls e expostos como média \pm E.P.M (* representa a comparação entre os grupos com RPMI em que $p<0,05$.).

\subsection{Camundongos deficientes em STING e TLR-9, mas não AIM2, possuem maior sobrevida após sepse letal}

Tendo em vista a alta concentração de DNA plasmático em pacientes com sepse e sua correlação com a gravidade e mortalidade dos pacientes (DWIVEDI et al., 2012; SAUKKONEN et al., 2008), nos questionamos se o DNA plasmático poderia estar atuando como DAMP através de receptores de DNA. Diversos receptores foram descritos por reconhecer DNA, entre eles STING, TLR-9 e AIM2. Para investigar a relação desses receptores na patologia da sepse, induzimos o modelo de sepse letal em animais deficientes desses receptores. Animais STING-'- , quando submetidos à CLP-L, apresentaram melhor sobrevida, 40\% maior que o grupo WT, onde observamos mortalidade de $100 \%$ (Figura 3A). O mesmo fenótipo foi observado para animais TLR9-, grupo que apresentou sobrevida entre $50 \%$ a $60 \%$. Entretanto, quando analisados os animais $\mathrm{AlM}^{-/}$, foi observado que o grupo possui mortalidade semelhante à CLP quando comparados aos animais WT, ou seja, todos os animais morreram em até 3 dias após a realização da cirurgia. 


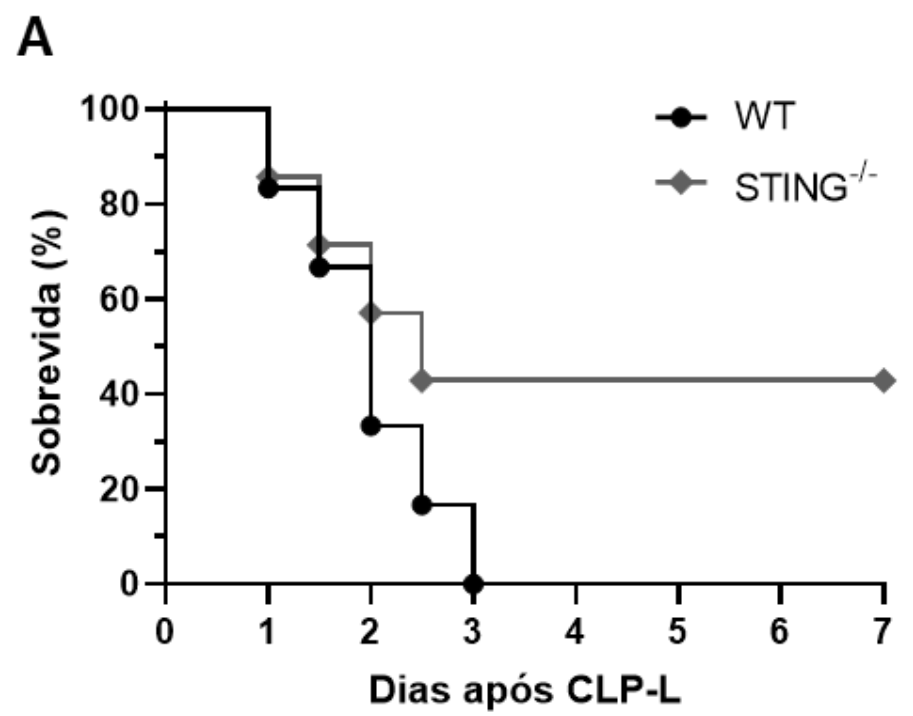

B

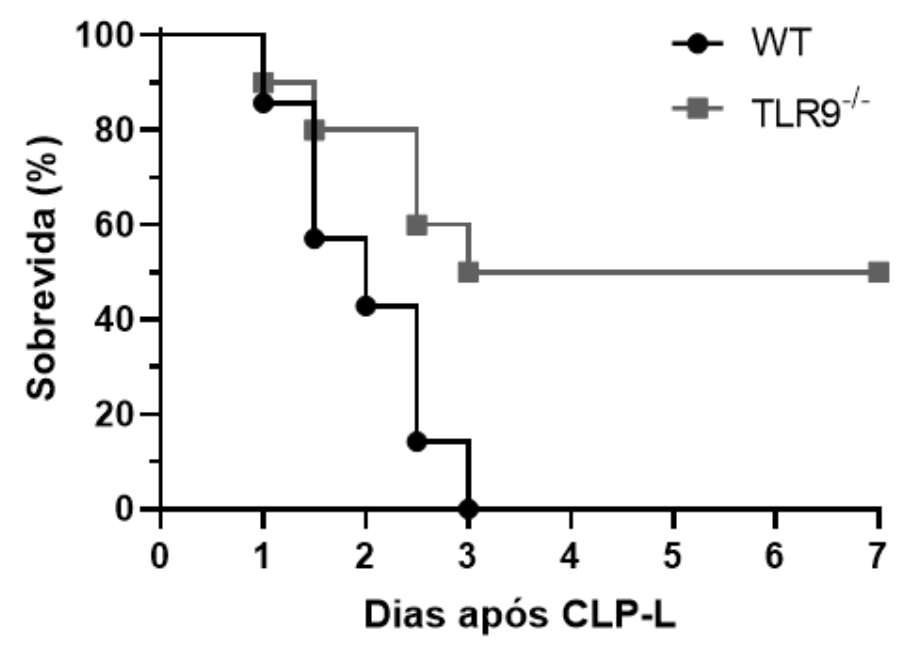

C

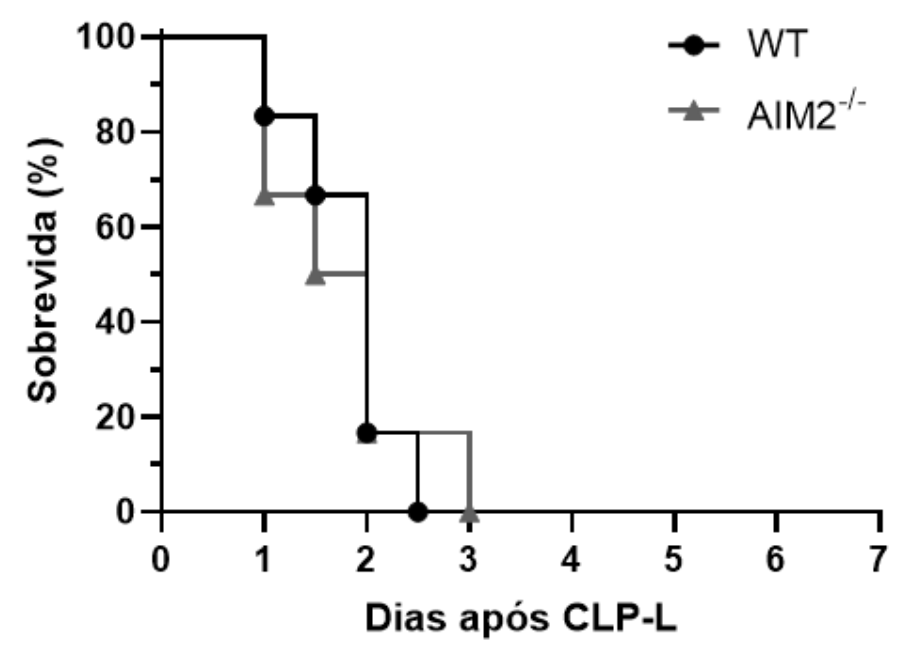


Figura 3. Camundongos deficientes nos receptores de DNA STING e TLR9, mas não AIM2, possuem uma maior resistência à CLP-L. A) Animais selvagens (WT) e STING ${ }^{-/}$foram submetidos à CLP-L, a sobrevida dos animais foi observada por 7 dias. B) Animais selvagens (WT) e TLR9 ${ }^{-/}$foram submetidos à CLP-L, a sobrevida dos animais foi observada por 7 dias. C) Animais selvagens (WT) e AIM2 ${ }^{-/}$foram submetidos à CLP-L, a sobrevida dos animais foi observada por 7 dias. A avaliação da diferença na curva de sobrevida foi analisada utilizando o teste Mantel-Cox logrank (nível de significância: $p<0,05$ ).

\subsection{A deficiência de STING está associada a uma menor disseminação bacteriana após sepse letal}

Ao avaliarmos a quantidade de bactérias presentes no sangue dos animais STING-- após a indução da sepse, notamos que a maior resistência à CLP-L desses animais está associada à menor disseminação bacteriana para a corrente sanguínea, avaliada pela determinação da quantidade de CFU por mililitro de sangue, 24 h após a indução da CLP-L, quando comparados aos animais WT (Figura 4A). O mesmo pode ser observado no foco inicial da infecção, pois animais WT apresentaram uma quantidade significativamente maior de bactérias no lavado peritoneal que os animais STING ${ }^{-1}$ (Figura 4B). 


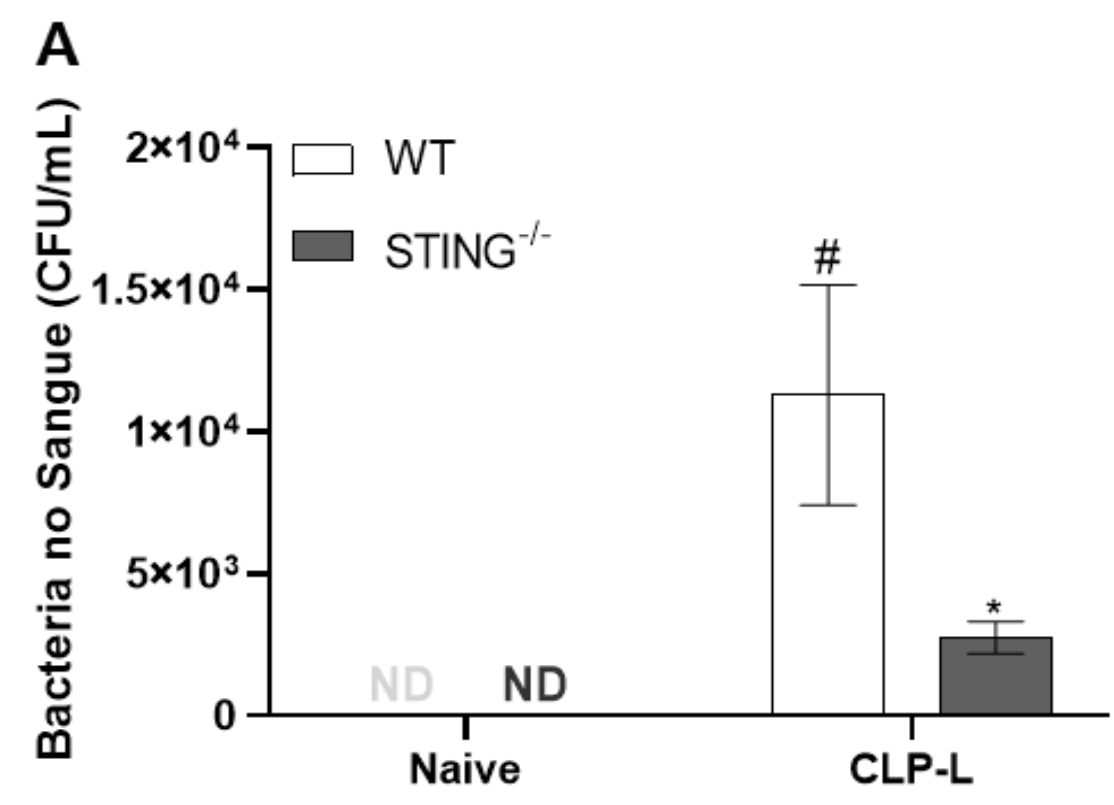

B

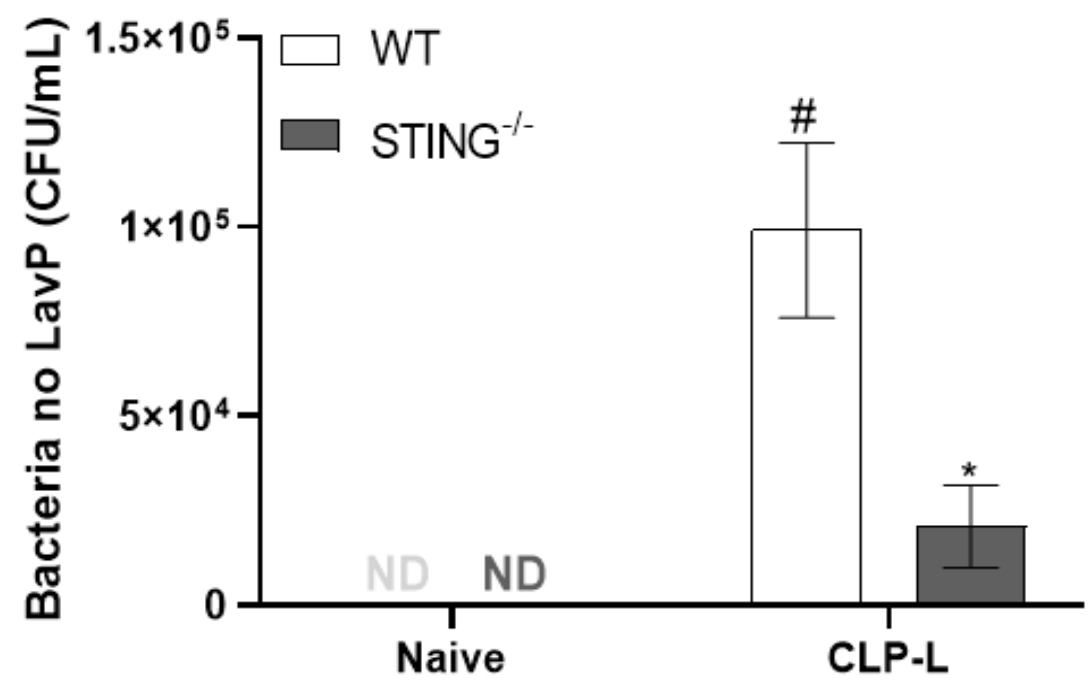

Figura 4. A deficiência do receptor STING está associada a uma menor disseminação bacteriana após CLP-L em camundongos. Animais selvagens (WT) e STING ${ }^{-1-}$ foram submetidos à CLP-L. Decorridas 24 horas, as amostras foram obtidas para a quantificação da carga bacteriana (A) As unidades formadoras de colônia (UFC) foram quantificadas no sangue coletado após a indução da sepse. B) As UFC foram quantificadas no lavado peritoneal coletado a indução da sepse. Os dados estão expressos como o número de UFC por mililitro de sangue (UFC/mL). Os resultados 
foram analisados por ANOVA seguida pelo teste de Newman-Keuls e expostos como média \pm E.P.M ( ${ }^{*}$ representa a comparação entre os grupos WT e STING ${ }^{-/}$em que $p<0,05$. \# representa a comparação entre os grupos sham em que $p<0,05$ no mesmo tempo analisado; $n=5-7$ animais/grupo, figura representativa de 3 experimentos independentes).

\subsection{A deficiência em STING está associada com menores concentrações} de DNA e NETs no plasma de camundongos após sepse letal

Sabendo que o DNA extracelular é um agente potencializador da sepse, e que altos níveis de NETs circulantes também estão descritos como promotores de dano tecidual na sepse (CZAIKOSKI et al., 2016), investigamos se a deficiência em STINGestaria resultando em menor produção de NETs e, consequentemente, aumentando a resistência dos animais à sepse. Primeiramente, verificamos que animais STING ${ }^{-1-}$ possuem uma menor concentração de DNA plasmático quando comparados a animais WT, 24 h após a CLP-L (Figura 5A). Posteriormente, avaliamos os níveis de NET no plasma desses animais, $24 \mathrm{~h}$ após a indução da CLP-L e observamos que o animais STING ${ }^{-/}$tiveram menores níveis de NETs circulantes quando comparados aos animais WT (Figura 5B). O mesmo perfil de menor produção de NETs observado no plasma do grupo STING ${ }^{-/-}$foi observado ao avaliarmos os níveis de NETs presentes no foco inicial da infecção, através da quantificação de NETs no lavado peritoneal, onde os mesmos também foram menores quando comparados aos animais WT (Figura 5C). 

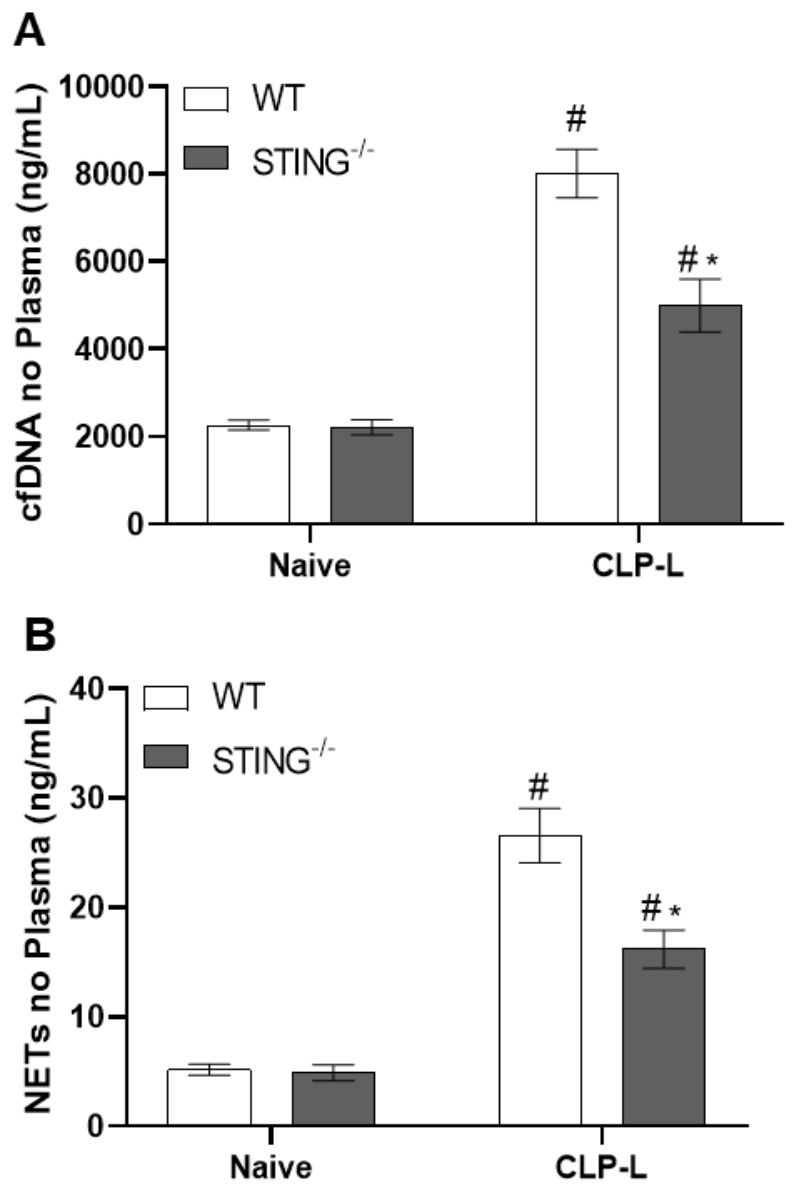

C

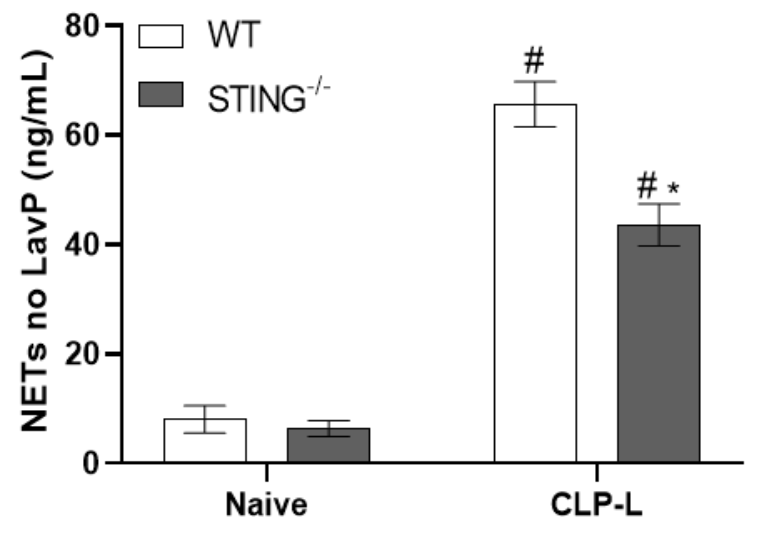

Figura 5. A deficiência em STING está associada com menores concentrações de DNA no plasma de camundongos após CLP-L. Animais selvagens (WT) e STING ${ }^{-1-}$ foram submetidos à CLP-L. Decorridas 24 horas, as amostras foram obtidas para a quantificação. (A) A concentração de cfDNA foi quantificada no plasma coletado após a indução da sepse. (B) A concentração de NETs foi quantificada no plasma coletado 
após a indução da sepse. (C) A concentração de NETs foi quantificada no lavado peritoneal coletado após a indução da sepse. Os dados estão expressos em ng por mililitro de amostra $(\mathrm{ng} / \mathrm{mL})$. Os resultados foram analisados por ANOVA seguida pelo teste de Newman-Keuls e expostos como média I E.P.M ( ${ }^{*}$ representa a comparação entre os grupos WT e STING ${ }^{-/}$em que $p<0,05$. \# representa a comparação entre os grupos sham em que $p<0,05$ no mesmo tempo analisado; $n=5-7$ animais/grupo, figura representativa de 3 experimentos independentes).

\subsection{A deficiência em STING está associada ao menor desenvolvimento de lesões orgânicas após sepse letal}

Estudos recentes do nosso grupo demonstraram que as NETs são associadas com o desenvolvimento de lesão orgânica durante a sepse (CZAIKOSKI et al., 2016). Tendo em vista uma melhor sobrevida e os menores níveis de NETs do grupo STING-CLP-L, verificamos se esses animais possuíam, também, um menor desenvolvimento de lesão orgânica decorrente da sepse. Para isso, avaliamos a atividade da enzima alanina aminotransferase (ALT), que está presente nas células do fígado e é comumente liberada quando há dano nessas células. Podemos observar que animais WT submetidos a sepse letal tiveram um aumento significativo nos níveis de ALT no plasma, já em animais STING ${ }^{-/}$esse aumento foi menor quando comparados aos animais WT, indicando, assim, uma menor extensão de lesão no fígado desses animais (Figura 6A). Para avaliar a presença de lesão cardíaca, foi avaliada a atividade da enzima creatina quinasse (CK-MB) no plasma. Podemos observar que animais deficientes para STING apresentaram um menor aumento da atividade plasmática da enzima CK-MB 24 h após a indução da CLP-L, indicando, assim, menos lesão cardíaca nesses animais (Figura 6B). Além disso, avaliamos os níveis sanguíneos de nitrogênio ureico (BUN), os quais são elevados quando há lesão renal. Conforme esperado, 
observamos que animais WT, quando submetidos a CLP-L, apresentam aumento nos níveis de BUN 24 h após a indução, enquanto animais deficientes em STING não apresentaram aumento nos níveis de ureia plasmática, indicando que esses animais possuem menos dano renal decorrente da sepse (Figura 6C). Com base nos marcadores observados podemos inferir que animais STING ${ }^{-/}$possuem menor lesão orgânica decorrente da sepse. 
A

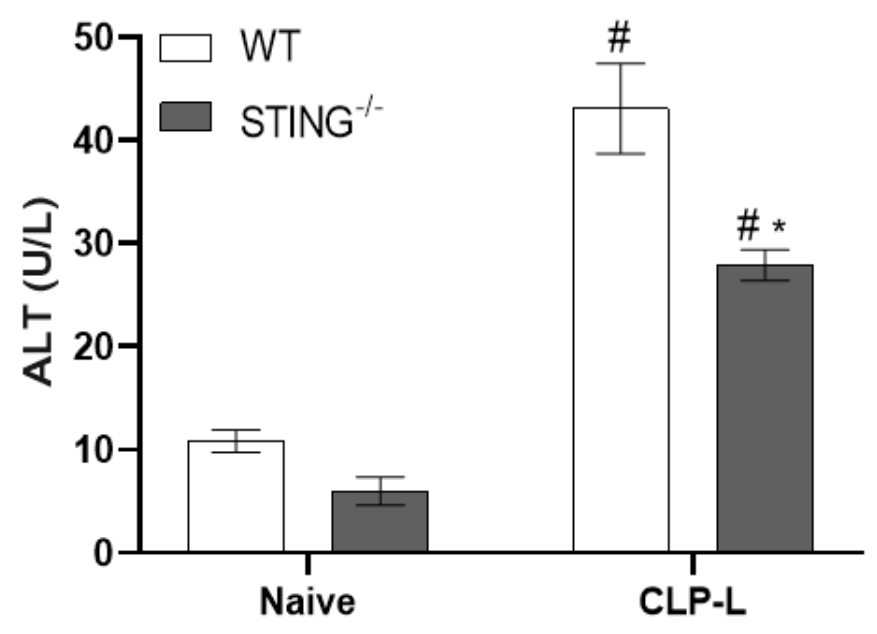

B

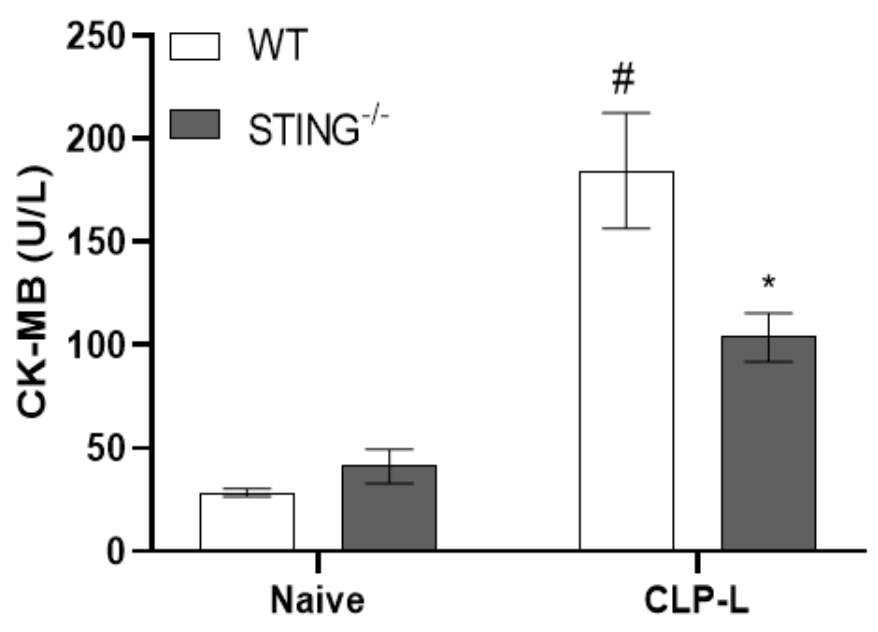

C

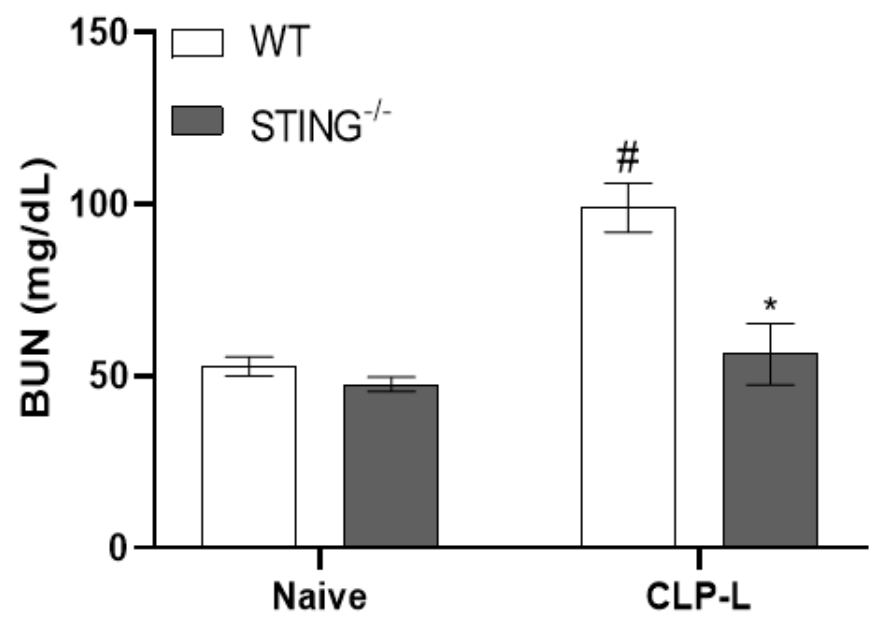


Figura 6. A deficiência em STING está associada ao menor desenvolvimento de lesões orgânicas após CLP-L. Animais selvagens (WT) e STING-/- foram submetidos à CLP-L. Decorridas 24 horas, as amostras foram obtidas para a quantificação. (A) A concentração de ALT foi quantificada no plasma coletado após a indução da sepse. (B) A concentração de CK-MB foi quantificada no plasma coletado após a indução da sepse. (C) A concentração de BUM foi quantificada no plasma coletado após a indução da sepse. Os dados estão expressos em unidades por litro $(U / L)$ nas figuras $A$ e $B$ e em unidades por decilitro $(\mathrm{U} / \mathrm{dL})$ na figura $C$. Os resultados foram analisados por ANOVA seguida pelo teste de Newman-Keuls e expostos como média \pm E.P.M ( ${ }^{*}$ representa a comparação entre os grupos WT e STING ${ }^{-/-}$em que $p<0,05$. \# representa a comparação entre os grupos sham em que $p<0,05$ no mesmo tempo analisado; $n=5-7$ animais/grupo, figura representativa de 3 experimentos independentes).

\subsection{A deficiência em STING resulta em menor produção de citocinas pró- inflamatórias após sepse letal}

A sepse é comumente caracterizada por elevada produção de citocinas circulantes, especialmente aquelas que desencadeiam efeitos de perfil pró-inflamatório. Animais WT submetidos à CLP-L tiveram aumento significativo, quando comparados ao grupo sham, na concentração de IL-6, TNF- $\alpha$ e IL-10 24 h após a indução. Por outro lado, corroborando os dados obtidos anteriormente, animais deficientes em STING apresentam significativamente menores níveis das mesmas citocinas, em comparação ao grupo WT (Figura 7A, B e C). 
A

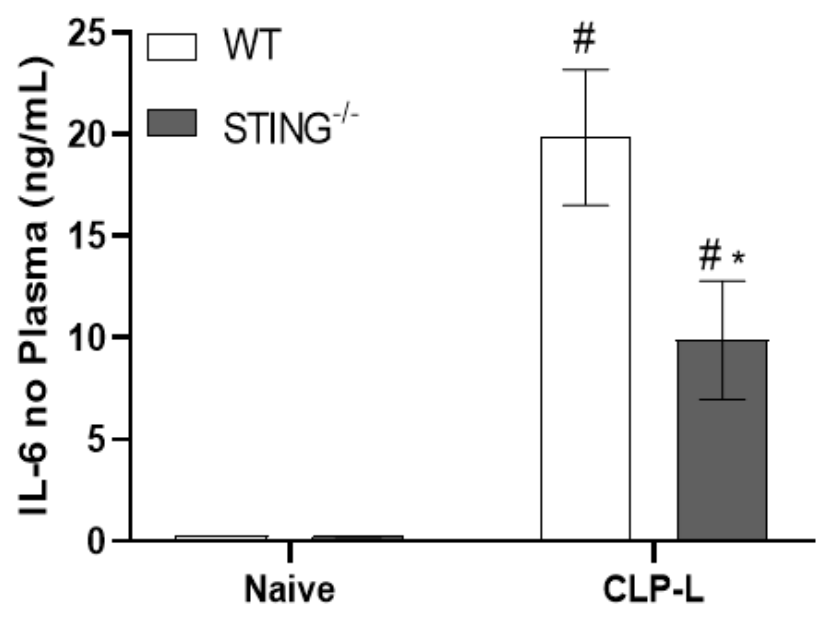

B

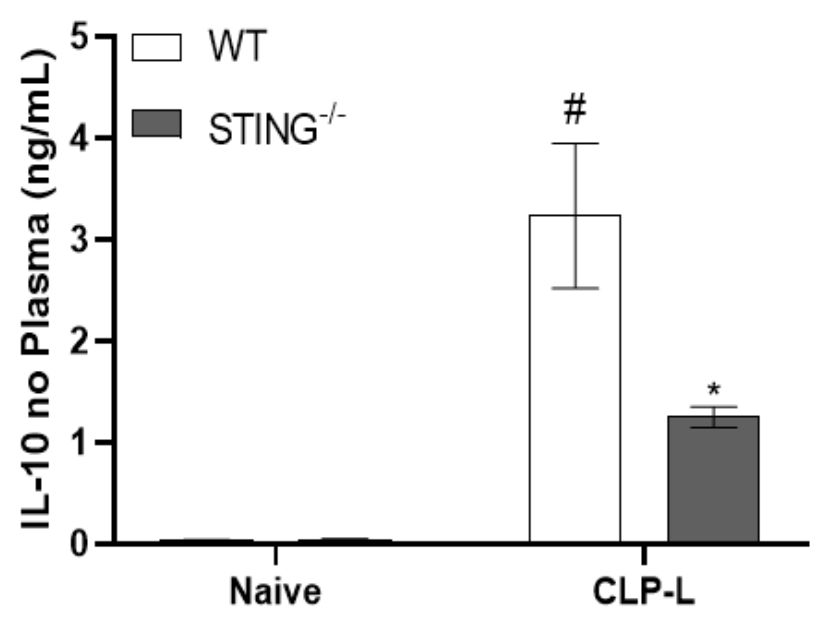

C

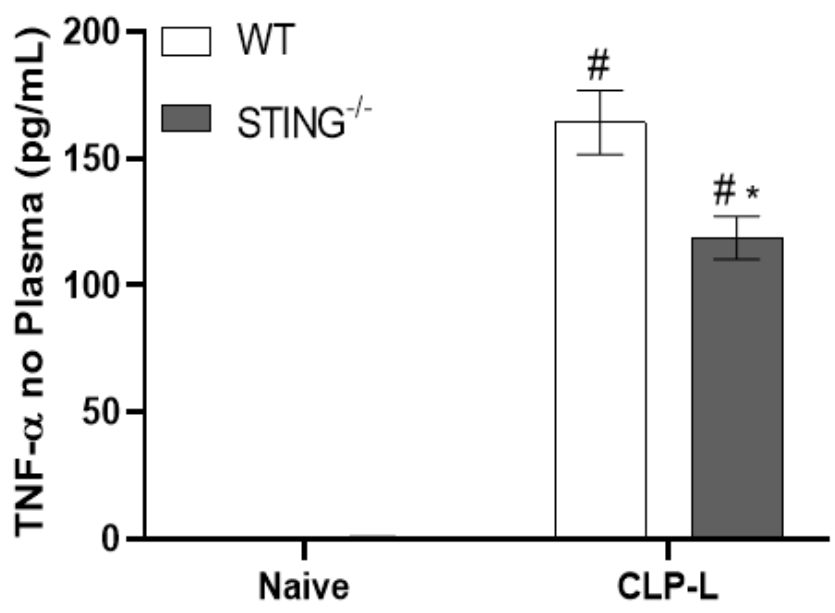


Figura 7. A deficiência em STING resulta em menor produção de citocinas inflamatórias após CLP-L. Animais selvagens (WT) e STING-/- foram submetidos à CLP-L. Decorridas 24 horas, as amostras foram obtidas para a quantificação. (A) A concentração de IL-6 foi quantificada no plasma coletado após a indução da sepse. (B) A concentração de IL-10 foi quantificada no plasma coletado após a indução da sepse. (C) A concentração de TNF- $\alpha$ foi quantificada no plasma coletado após a indução da sepse. Os dados estão expressos em nanogramas por mililitro $(\mathrm{ng} / \mathrm{mL})$ nas figuras $A$ e $B$ e em pictogramas por $\mathrm{mL}(\mathrm{pg} / \mathrm{mL})$ na figura $C$. Os resultados foram analisados por ANOVA seguida pelo teste de Newman-Keuls e expostos como média \pm E.P.M ( ${ }^{*}$ representa a comparação entre os grupos WT e STING-- em que $p<0,05$. \# representa a comparação entre os grupos sham em que $p<0,05$ no mesmo tempo analisado; $n=5-7$ animais/grupo, figura representativa de 3 experimentos independentes). 


\section{DISCUSSÃO}

A sepse é, na maioria dos casos, caracterizada como uma resposta inflamatória sistêmica exacerbada decorrente de uma infecção, na qual o paciente apresenta lesão de órgãos com potencial risco à vida (SINGER et al., 2016). O modelo de CLP é considerado o padrão ouro para estudos envolvendo a sepse, tratando-se de um procedimento simples e de baixo custo, que mimetiza várias características da sepse (WEN, 2013). Nesse modelo, a severidade pode ser controlada através do calibre da agulha usada para perfurar o ceco, bem como a quantidade de perfurações feitas no ceco e a quantidade de conteúdo cecal liberado para cavidade peritoneal. O modelo de CLP pode ser induzido em diferentes graus de gravidade, na sepse que, didaticamente, consideramos moderada, a taxa de mortalidade no grupo em cerca de $50 \%$, já na sepse letal, a taxa de mortalidade é de $100 \%$. Na sepse letal, podemos observar uma maior carga bacteriana, tanto sistêmica quanto no foco da infecção, além disso, esse modelo mimetiza outros parâmetros, como uma maior produção de citocinas, o aumento das lesões de órgãos, além da falha da migração de neutrófilos para o foco da infecção e uma maior quantidade dessas células em órgãos não infectados.

Neste trabalho, identificamos que o estímulo de neutrófilos com diferentes tipos DNA tem como consequência a produção de NETs, com mecanismo dependente da ativação de STING. Também verificamos que camundongos submetidos ao modelo de sepse letal apresentam aumento na quantidade de cfDNA e que camundongos deficientes para STING apresentam maior resistência ao modelo de sepse letal. Além disso, esses animais apresentam uma menor concentração de cfDNA e menos NETs, tanto no lavado peritoneal quando no plasma, bem como uma menor quantidade de bactérias quando comparados com animais selvagens. Esses animais também 
apresentam menor lesão em órgãos não infectados, como coração, fígado e rins, além de apresentar uma menor concentração de citocinas, tanto pro-inflamatórias quando anti-inflamatórias.

Diversos estudos vêm mostrando que cfDNA está presente em grandes concentrações no plasma de pacientes com sepse e que o aumento das concentrações plasmáticas de DNA está diretamente correlacionado com a gravidade do quadro séptico, avaliados pelo SOFA, e com a mortalidade desses pacientes (CLEMENTI et al., 2016; JACKSON CHORNENKI et al., 2019; SAUKKONEN et al., 2008). No presente estudo demonstramos que a concentração de cfDNA está presente no modelo de CLP, e que sua concentração se eleva de acordo com o tempo após a indução da sepse. Além disso, demonstramos também que animais submetidos ao modelo de sepse letal possuem uma maior concentração de cfDNA no plasma quando comparados aos animais submetidos a sepse moderada, reproduzindo o fenótipo observado na clínica onde as concentrações de cfDNA observadas são diretamente proporcionais à gravidade do quadro de sepse.

Até recentemente, acreditava-se que o cfDNA possuía a função apenas de biomarcador, sendo reflexo dos eventos de morte celular que ocorrem durante o dano tecidual. No entanto, diversos estudos vêm demonstrando que o cfDNA desempenha uma função patológica em diversas doenças, podendo ativar células através dos receptores de DNA (BRONKHORST; UNGERER; HOLDENRIEDER, 2019; DUVVURI; LOOD, 2019).

O organismo possui uma série de PRRs responsáveis por detectar os mais variados tipos de antígenos, entre eles o DNA. Os receptores de DNA vêm sendo descritos por desempenhar importantes papéis em diversas doenças inflamatórios, 
incluindo a sepse (ORI; MURASE; KAWAI, 2017; ROERS; HILLER; HORNUNG, 2016). Nesse sentido, avaliamos a relação dos receptores de DNA com a patologia da sepse, através de animais deficientes dos receptores TLR9, AIM2 e STING, conhecidos por reconhecer DNA de dupla fita. Verificamos que animais deficientes em TLR9 e STING, mas não em AIM2, são mais resistentes à sepse, pois quando submetidos ao modelo de sepse letal é possível ver que o grupo apresenta uma maior sobrevida comparados aos camundongos selvagens.

A importância do cfDNA e dos receptores de DNA no processo patológico vem sendo discutida por numerosos estudos. Usando um modelo de inflamação pulmonar por sílica, Benmerzoug e colaboradores demonstraram que o DNA de dupla fita presente no pulmão é capaz de agravar a resposta inflamatória pós exposição à sílica através da ativação de STING. Além disso, o tratamento com DNAse foi capaz de amenizar a inflamação pulmonar, além de diminuir a ativação de STING (BENMERZOUG et al., 2018). Em um estudo publicado recentemente, foi demonstrado que o DNA mitocondrial é capaz de ativar neutrófilos e induzir a produção de NETs, essa ativação se dá de maneira dependente de STING, o que resulta em lesão pulmonar (LIU et al., 2019). Um estudo anterior de nosso grupo demonstrou que a proteção de animais deficientes para TLR9 está relacionada com a maior migração de neutrófilos para o foco da infeção. Esse mesmo estudo identificou, ainda, que a ativação de TLR9 induz a internalização do receptor de quimiocinas CXCR2, levando a falha da migração (TREVELIN et al., 2012).

No presente estudo verificamos que nDNA, mtDNA e bacDNA foram capazes de induzir a produção de NETs por neutrófilos, in vitro, Além disso, também verificamos que animais deficientes em STING possuem uma menor concentração plasmática de 
cfDNA, além de apresentar menos NETs, tanto no plasma quanto no lavado peritoneal. As NETs aparentam desempenhar um importante papel na fisiopatologia da sepse, foi demonstrado pelo nosso grupo que animais tratados com DNAse, juntamente com antibiótico de amplo espectro, possuem menor susceptibilidade à CLP-L (CZAIKOSKI et al., 2016). Outro estudo do grupo demonstrou que o grupo de animais infantes tratados antibiótico, em combinação com cl-amidina, um inibidor de PAD4, possui sobrevida significantemente maior, quando comparados aosanimais tratados apenas com o antibiótico (COLÓN et al., 2019). Esses estudos demonstram a importância das NETs no processo patológico da sepse.

A carga bacteriana presente na circulação sanguínea e no foco da infecção levam à exacerbação da resposta inflamatória. Em nosso estudo, podemos verificar que animais deficientes em STING quando submetidos à CLP-L, apresentaram uma menor carga bacteriana, tanto no sangue quanto no lavado peritoneal, em comparação com animais selvagens. Esses dados estão de acordo com a literatura que mostra que animais deficientes em STING possuem uma menor carga bacteriana após a indução da sepse, no modelo de CLP-L (HEIPERTZ; HARPER; WALKER, 2017).

Um dos melhores meios para quantificar a resposta inflamatória sistêmica é através da dosagem de mediadores inflamatórios, como as citocinas. Na sepse há um aumento, tanto de citocinas pro-inflamatórias, como IL-6 e TNF- $\alpha$, quanto de citocinas anti-inflamatórias, como a IL-10. Esses níveis aumentados de mediadores levam à desregulação da resposta imune, resultando em falha do controle da infecção, além das lesões de órgãos. Em nosso estudo, quando avaliados esses parâmetros, podemos verificar que animais deficientes em STING submetidos a CLP-L apresentaram uma menor concentração das citocinas IL-6, IL-10 e TNF- $\alpha$. 
Uma das principais características da sepse é a lesão de órgãos resultante da resposta inflamatória desregulada (STEARNS-KUROSAWA et al., 2011). As NETs são outros fatores que levam às lesões de órgãos. Tendo em vista que animais deficientes em STING possuem uma menor carga bacteriana, concentração de NETs e citocinas no sangue, avaliamos a concentração de marcadores bioquímicos de lesões de órgãos. Podemos verificar que, após 24 horas da indução da sepse, camundongos deficientes em STING apresentaram uma menor concentração de ALT, enzima que se encontra aumentada quando se há lesão hepática. Além disso, os níveis de CKMB também foram menores, indicando menor lesão cardíaca. Quando avaliado os níveis plasmáticos de ureia, também observamos uma menor concentração nos animais deficientes para STING, indicando uma proteção renal, quando comparado a animais WT. 


\section{CONCLUSÃO}

Com base nos nossos dados podemos concluir que o DNA extracelular leva à ativação de receptores de DNA em neutrófilos, induzindo a formação de NETs e que os receptores de STING, mas não do AIM2, estão relacionados com a progressão da sepse no modelo de CLP-L. Isso contribui para a formação de NETs e para a inflamação e lesão de órgãos no modelo, onde animais deficientes em STING possuem uma maior taxa de sobrevida e menor carga bacteriana, além de possuírem menores níveis de marcadores de lesão e de citocinas no plasma. 


\section{BIBLIOGRAFIA}

AHN, Jeonghyun; BARBER, Glen N. Self-DNA, STING-dependent signaling and the origins of autoinflammatory disease. Current Opinion in Immunology, v. 31, p. 121126, dez. 2014.

ALVES-FILHO, J C et al. Regulation of chemokine receptor by Toll-like receptor 2 is critical to neutrophil migration and resistance to polymicrobial sepsis. Proc Natl Acad Sci U S A, v. 106, n. 10, p. 4018-4023, mar. 2009.

ALVES-FILHO, José Carlos et al. Failure of neutrophil migration toward infectious focus in severe sepsis: A critical event for the outcome of this syndrome. Memorias do Instituto Oswaldo Cruz, v. 100, n. SUPPL. 1, p. 223-226, 2005.

ANGUS, Derek C. et al. Epidemiology of severe sepsis in the United States: Analysis of incidence, outcome, and associated costs of care. Critical Care Medicine, v. 29, n. 7, p. 1303-1310, jul. 2001.

BENJAMIM, C. F.; FERREIRA, S. H.; CUNHA, F. D.Q. Role of nitric oxide in the failure of neutrophil migration in sepsis. Journal of Infectious Diseases, v. 182, n. 1, p. 214-223, 2000.

BENMERZOUG, Sulayman et al. STING-dependent sensing of self-DNA drives silica-induced lung inflammation. Nature Communications, v. 9, n. 1, p. 5226, 2018. Disponível em: <https://doi.org/10.1038/s41467-018-07425-1>.

BONE, R. C. et al. Definitions for sepsis and organ failure and guidelines for the use of innovative therapies in sepsis. Chest, v. 101, n. 6, p. 1644-1655, jun. 1992.

BOSMANN, Markus; WARD, Peter A. The inflammatory response in sepsis. Trends in Immunology, v. 34, n. 3, p. 129-136, 2013.

BRINKMANN, Volker et al. Neutrophil Extracellular Traps Kill Bacteria. Science, 
v. 303 , n. 5663 , p. 1532-1535, mar. 2004.

BRONKHORST, Abel Jacobus; UNGERER, Vida; HOLDENRIEDER, Stefan. The emerging role of cell-free DNA as a molecular marker for cancer management. Biomolecular Detection and Quantification, v. 17, p. 100087, 2019. Disponível em: <http://www.sciencedirect.com/science/article/pii/S221475351830024X>.

BURDETTE, Dara L. et al. STING is a direct innate immune sensor of cyclic diGMP. Nature, v. 478, n. 7370, p. 515-518, set. 2011.

CAMICIA, Gabriela; POZNER, Roberto; DE LARRAÑAGA, Gabriela. Neutrophil extracellular traps in sepsis. Shock, v. 42, n. 4, p. 286-294, 2014.

CLEMENTI, Anna et al. The Role of Cell-Free Plasma DNA in Critically III Patients with Sepsis. Blood Purification, v. 41, n. 1-3, p. 34-40, 2016.

COLÓN, David F. et al. Neutrophil extracellular traps (NETs) exacerbate severity of infant sepsis. Critical Care, v. 23, n. 1, p. 113, abr. 2019.

CONDE, Katia Aparecida Pessoa et al. Differences in Sepsis Treatment and Outcomes between Public and Private Hospitals in Brazil: A Multicenter Observational Study. PLOS ONE, v. 8, n. 6, p. e64790, 2013.

CZAIKOSKI, Paula Giselle et al. Neutrophil extracellular traps induce organ damage during experimental and clinical sepsis. PLOS ONE, v. 11, n. 2, p. e0148142, 2016.

DUVVURI, Bhargavi; LOOD, Christian. Cell-free DNA as a biomarker in autoimmune rheumatic diseases. Frontiers in Immunology, v. 10, n. MAR, p. 502, 2019.

DWIVEDI, Dhruva J. et al. Prognostic utility and characterization of cell-free DNA in patients with severe sepsis. Critical Care, v. 16, n. 4, 2012.

FUNK, Duane J.; PARRILLO, Joseph E.; KUMAR, Anand. Sepsis and Septic 
Shock: A History. Critical Care Clinics, v. 25, n. 1, p. 83-101, 2009. Disponível em: <http://dx.doi.org/10.1016/j.ccc.2008.12.003>.

GAO, Ming et al. Toll-like receptor 3 plays a central role in cardiac dysfunction during polymicrobial sepsis. Critical Care Medicine, v. 40, n. 8, p. 2390-2399, 2012.

GUIMARÃES-COSTA, Anderson B. et al. Leishmania amazonensis promastigotes induce and are killed by neutrophil extracellular traps. Proceedings of the National Academy of Sciences of the United States of America, v. 106, n. 16, p. 67486753, abr. 2009.

GYAWALI, Bishal; RAMAKRISHNA, Karan; DHAMOON, Amit S. Sepsis: The evolution in definition, pathophysiology, and management. SAGE Open Medicine, v. 7, p. $205031211983504,2019$.

HAMAGUCHI, Shigeto et al. Origin of circulating free DNA in sepsis: Analysis of the CLP mouse model. Mediators of Inflammation, v. 2015, 2015.

HEIPERTZ, Erica L.; HARPER, Jourdan; WALKER, Wendy E. STING and TRIF Contribute to Mouse Sepsis, Depending on Severity of the Disease Model. Shock, v. 47, n. 5, p. 621-631, 2017.

HIROKI, Carlos H. et al. Neutrophil Extracellular Traps Effectively Control Acute Chikungunya Virus Infection. Frontiers in Immunology, v. 10, p. 3108, 2020.

HOTCHKISS, Richard S. et al. Sepsis and septic shock. Nature Reviews Disease Primers, v. 2, n. June, p. 16045, 2016. Disponível em: <http://www.nature.com/articles/nrdp201645>.

JACKSON CHORNENKI, Nicholas L. et al. Comparison of the source and prognostic utility of cfDNA in trauma and sepsis. Intensive Care Medicine Experimental, v. 7, n. 1, 2019. 
JANEWAY, Charles A. How the immune system protects the host from infection. Microbes and Infection, v. 3, n. 13, p. 1167-1171, nov. 2001.

JANEWAY, Charles A.; MEDZHITOV, Ruslan. Innate immune recognition. Annual Review of Immunology, v. 20, p. 197-216, 2002.

KOVACH, Melissa A.; STANDIFORD, Theodore J. The function of neutrophils in sepsis. Current Opinion in Infectious Diseases, v. 25, n. 3, p. 321-327, 2012.

LAUKOVÁ, Lucia et al. Early Dynamics of Plasma Dna in a Mouse Model of Sepsis. Shock, v. 52, n. 2, p. 257-263, jul. 2019.

LEE, Seonmin et al. NLRP3 inflammasome deficiency protects against microbial sepsis via increased lipoxin B4 synthesis. American Journal of Respiratory and Critical Care Medicine, v. 196, n. 6, p. 713-726, set. 2017.

LI, Ning et al. STING-IRF3 contributes to lipopolysaccharide-induced cardiac dysfunction, inflammation, apoptosis and pyroptosis by activating NLRP3. Redox Biology, v. 24, n. May, p. 101215, 2019. Disponível em: <https://doi.org/10.1016/j.redox.2019.101215>.

LIU, Li et al. Induction of neutrophil extracellular traps during tissue injury: Involvement of STING and Toll-like receptor 9 pathways. Cell Proliferation, v. 52, n. 3, p. e12579, maio 2019.

LIU, Vincent et al. Hospital deaths in patients with sepsis from 2 independent cohorts. JAMA - Journal of the American Medical Association, v. 312, n. 1, p. 90-92, jul. 2014.

MACHADO, Flavia R. et al. The epidemiology of sepsis in Brazilian intensive care units (the Sepsis PREvalence Assessment Database, SPREAD): An observational study. The Lancet Infectious Diseases, v. 17, n. 11, p. 1180-1189, nov. 2017. 
MAGNA, Melinda; PISETSKY, David S. The Alarmin Properties of DNA and DNAassociated Nuclear Proteins. Clinical Therapeutics, v. 38, n. 5, p. 1029-1041, 2016. Disponível em: <http://dx.doi.org/10.1016/j.clinthera.2016.02.029>.

MAN, Si Ming; KARKI, Rajendra; KANNEGANTI, Thirumala Devi. AIM2 inflammasome in infection, cancer, and autoimmunity: Role in DNA sensing, inflammation, and innate immunity. European Journal of Immunology, v. 46, n. 2, p. 269-280, fev. 2016.

MANDEL, P.; METAIS, P. Les acides nucléiques du plasma sanguin chez l'homme. Comptes rendus des séances de la Société de biologie et de ses filiales, v. 142, n. 3-4, p. 241-243, fev. 1948.

MARSMAN, Gerben; ZEERLEDER, Sacha; LUKEN, Brenda M. Extracellular histones, cell-free DNA, or nucleosomes: differences in immunostimulation. Cell death \& disease, v. 7, n. 12, p. e2518, dez. 2016.

MEDZHITOV, R.; JANEWAY C., Jr. Advances in immunology: Innate immunity. New England Journal of Medicine, v. 343, n. 5, p. 338-344, 3 ago. 2000. Disponível em: <https://doi.org/10.1056/NEJM200008033430506>.

MEDZHITOV, Ruslan. Recognition of microorganisms and activation of the immune response. Nature, v. 449, n. 7164, p. 819-826, out. 2007.

NEIRA, Ricardo Alfredo Quintano; HAMACHER, Silvio; JAPIASSU, Andre Miguel. Epidemiology of sepsis in Brazil: Incidence, lethality, costs, and other indicators for Brazilian Unified Health System hospitalizations from 2006 to 2015. PLoS ONE, v. 13, n. 4, p. 1-15, 2018.

O'BRIEN, Xian M.; BIRON, Bethany M.; REICHNER, Jonathan S. Consequences of extracellular trap formation in sepsis. Current Opinion in Hematology, v. 24, n. 1, p. 
66-71, 2017.

ORI, Daisuke; MURASE, Motoya; KAWAI, Taro. Cytosolic nucleic acid sensors and innate immune regulation. International Reviews of Immunology, v. 36, n. 2, p. $74-$ 88, 2017. Disponível em: <http://dx.doi.org/10.1080/08830185.2017.1298749>.

PAPAYANNOPOULOS, Venizelos. Neutrophil extracellular traps in immunity and disease. Nature Reviews Immunology, v. 18, n. 2, p. 134-147, 2018.

PLITAS, George et al. Toll-like receptor 9 inhibition reduces mortality in polymicrobial sepsis. The Journal of Experimental Medicine, v. 205, n. 6, p. 1277-1283, 2008. Disponível em: <http://www.jem.org/lookup/doi/10.1084/jem.20080162>.

RHODES, Andrew; CECCONI, Maurizio. Cell-free DNA and outcome in sepsis. Critical Care, v. 16, n. 6, p. 170, 2012.

ROERS, Axel; HILLER, Björn; HORNUNG, Veit. Recognition of Endogenous Nucleic Acids by the Innate Immune System. Immunity, v. 44, n. 4, p. 739-754, 2016.

RUDD, Kristina E. et al. Global, regional, and national sepsis incidence and mortality, 1990-2017: analysis for the Global Burden of Disease Study. The Lancet, v. 395, n. 10219, p. 200-211, jan. 2020.

SALES JÚNIOR, João Andrade L. et al. Sepse Brasil: estudo epidemiológico da sepse em Unidades de Terapia Intensiva brasileiras. Revista Brasileira de Terapia Intensiva, v. 18, n. 1, p. 9-17, mar. 2006. Disponível em: <http://www.scielo.br/scielo.php?script=sci_arttext\&pid=S0103507X2006000100003\&lng=pt\&nrm=iso\&tlng=pt>. Acesso em: 11 jan. 2019.

SAUKKONEN, Katri et al. Cell-free plasma DNA as a predictor of outcome in severe sepsis and septic shock. Clinical Chemistry, v. 54, n. 6, p. 1000-1007, 2008.

SHEN, Xiao Fei et al. Neutrophil dysregulation during sepsis: an overview and 
update. Journal of Cellular and Molecular Medicine, v. 21, n. 9, p. 1687-1697, set. 2017. Disponível em: <https://pubmed.ncbi.nlm.nih.gov/28244690>.

SINGER, Mervyn et al. The third international consensus definitions for sepsis and septic shock (sepsis-3). JAMA - Journal of the American Medical Association, v. 315, n. 8, p. 801-810, 2016.

SÔNEGO, Fabiane et al. Paradoxical roles of the neutrophil in sepsis: Protective and deleterious. Frontiers in Immunology, v. 7, n. APR, p. 1-7, 2016.

STEARNS-KUROSAWA, Deborah J. et al. The pathogenesis of sepsis. Annual Review of Pathology: Mechanisms of Disease, PMID: 20887193, v. 6, n. 1, p. 19-48, 2011. Disponível em: <https://doi.org/10.1146/annurev-pathol-011110-130327>.

STEWART, Caitlin M. et al. The value of cell-free DNA for molecular pathology. Journal of Pathology, v. 244, n. 5, p. 616-627, abr. 2018.

TAKEUCHI, Osamu; AKIRA, Shizuo. Pattern Recognition Receptors and Inflammation. Cell, v. 140, n. 6, p. 805-820, 19 mar. 2010. Disponível em: <https://doi.org/10.1016/j.cell.2010.01.022>.

THIAMA, Hawa Racine et al. NETosis proceeds by cytoskeleton and endomembrane disassembly and PAD4-mediated chromatin decondensation and nuclear envelope rupture. Proceedings of the National Academy of Sciences of the United States of America, v. 117, n. 13, p. 7326-7337, 2020.

TORIO, Celeste M; MOORE, Brian J. National Inpatient Hospital Costs: The Most Expensive Conditions by Payer, 2013: Statistical Brief \#204. Healthcare Cost and Utilization Project (HCUP) Statistical Briefs. Rockville (MD): [s.n.], 2006. . Disponível em: <http://www.ncbi.nlm.nih.gov/pubmed/27359025>.

TREVELIN, Silvia C. et al. Toll-like receptor 9 activation in neutrophils impairs 
chemotaxis and reduces sepsis outcome*. Critical Care Medicine, v. 40, n. 9, p. 26312637, 2012.

URBAN, Constantin F. et al. Neutrophil extracellular traps capture and kill Candida albicans and hyphal forms. Cellular Microbiology, v. 8, n. 4, p. 668-676, abr. 2006.

WANG, Yanming et al. Histone hypercitrullination mediates chromatin decondensation and neutrophil extracellular trap formation. Journal of Cell Biology, v. 184, n. 2, p. 205-213, jan. 2009.

WEN, Haitao. Sepsis induced by cecal ligation and puncture. Methods in Molecular Biology, v. 1031, p. 117-124, 2013. Disponível em: <https://pubmed.ncbi.nlm.nih.gov/23824895>.

ZHANG, Fang et al. Neutrophil dysfunction in sepsis. Chinese Medical Journal, v. 129, n. 22, p. 2741-2744, 2016. 